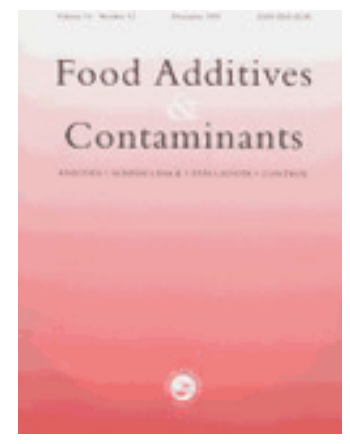

\title{
Potential of an in vitro toolbox combined with exposure data as a first step for the risk assessment of dietary chemical contaminants
}

\begin{tabular}{|c|c|}
\hline Journal: & Food Additives and Contaminants \\
\hline Manuscript ID: & TFAC-2011-021.R1 \\
\hline Manuscript Type: & Original Research Paper \\
\hline $\begin{array}{r}\text { Date Submitted by the } \\
\text { Author: }\end{array}$ & 11-Apr-2011 \\
\hline Complete List of Authors: & $\begin{array}{l}\text { Ribonnet, Laurence; Université catholique de Louvain, Institut des } \\
\text { Sciences de la Vie } \\
\text { Van der Heiden, Edwige; University of Liège, Department of Food } \\
\text { Sciences } \\
\text { Nobels, Ingrid; University of Antwerp, Laboratory of Ecophysiology, } \\
\text { Biochemistry and Toxicology } \\
\text { Chaumont, Agnès; Université catholique de Louvain, Institut des } \\
\text { Sciences de la Vie } \\
\text { Remacle, Anne-Sophie; University of Liège, Department of Food } \\
\text { Sciences } \\
\text { De Saeger, Sarah; Ghent University, Laboratory of Food Analysis } \\
\text { Schneider, Yves-Jacques; Université catholique de Louvain, Institut } \\
\text { des Sciences de la Vie } \\
\text { Scippo, Marie-Louise; University of Liège, Department of Food } \\
\text { Sciences } \\
\text { Blust, Ronny; University of Antwerp, Laboratory of Ecophysiology, } \\
\text { Biochemistry and Toxicology } \\
\text { Pussemier, Luc; CODA-CERVA-VAR } \\
\text { Larondelle, Yvan; Université catholique de Louvain, Institut des } \\
\text { Sciences de la Vie }\end{array}$ \\
\hline Methods/Techniques: & $\begin{array}{l}\text { Bioassay, Receptors, Toxicology - cytotoxicity, Screening - } \\
\text { microbial screening }\end{array}$ \\
\hline Additives/Contaminants: & Mycotoxins, Pesticide residues \\
\hline Food Types: & \\
\hline
\end{tabular}


In vitro risk assessment of dietary contaminants has become a priority in human food safety. In the present paper, we propose an in vitro approach associating different complementary tools in an original toolbox aiming at improving the assessment of the toxicological impact of dietary contaminants at realistic human exposure levels, with a special focus on the intestinal compartment. The system is based on the use of four complementary cellular tools, namely stress gene induction in transgenic strains of Escherichia coli, modulation of the activity of key biotransformation enzymes (cytochrome P-450 (CYP) 1A1 and 3A4) in a human intestinal cell line, and activation of aryl hydrocarbon receptor (AhR) and estrogenic receptor (ER)-dependent genes in agonistic and antagonistic assays with luciferase reporter cells. It was applied to four chosen model molecules: ochratoxin A (OTA) and

Abstract: deoxynivalenol (DON), two common food-borne mycotoxins, and imazalil (IMA) and benomyl (BEN), two fungicides widely recovered in foodstuffs. All these assays were performed at or around a realistic intestinal concentration, determined through a deterministic approach based on the calculation of a theoretical maximum daily intake (TMDI). Using the four model molecules, we clearly highlighted that induction of CYP1A1 activity and inhibition of CYP3A4 activity occurred in Caco-2 cells at a realistic intestinal concentration of IMA. Furthermore, some bacterial stress genes were induced in a range of realistic concentrations, following exposure to DON and IMA. In addition, BEN clearly provoked an ER agonistic activity in a human estrogen sensitive reporter cell line. All these results are in accordance with literature, suggesting that our in vitro toolbox constitutes an interesting approach in order to obtain a first 'fingerprint' of dietary contaminants at realistic human exposure for further risk assessment. 
1 Potential of an in vitro toolbox combined with exposure data as a first 2 step for the risk assessment of dietary chemical contaminants 3

4 L. Ribonnet ${ }^{\mathrm{a}, \text { e }}$, E. Van der Heiden ${ }^{\mathrm{b}}$, I. Nobels ${ }^{\mathrm{c}}$, A. Chaumont ${ }^{\mathrm{a}}$, A.-S. Remacle ${ }^{\mathrm{b}}$, S. De 5 Saeger $^{\mathrm{d}}$, Y.-J. Schneider ${ }^{\mathrm{a}}$, M.-L. Scippo ${ }^{\mathrm{b}}$, R. Blust $^{\mathrm{c}}$, L. Pussemier ${ }^{\mathrm{e}}$ and Y. Larondelle ${ }^{\mathrm{a}}$ 6

$7 \quad{ }^{a}$ Institut des Sciences de la Vie, Université catholique de Louvain, Croix du Sud 2/8 and 8 5/3, B-1348 Louvain-la-Neuve, Belgium

$9{ }^{b}$ Laboratory of Food Analysis, Department of Food Sciences, Faculty of Veterinary 10 Medicine, Centre for Analytical Research and Technology (CART), University of Liège, 11 Boulevard de Colonster 20, B-4000 Liège, Belgium

$12{ }^{\mathrm{c}}$ Laboratory of Ecophysiology, Biochemistry and Toxicology, University of Antwerp, 13 Groenenborgerlaan 171, B-2020 Antwerp, Belgium

14 d Laboratory of Food Analysis, Faculty of Pharmaceutical Sciences, Ghent University, 15 Harelbekestraat 72, B-9000 Ghent, Belgium

16 e Veterinary and Agrochemical Research Centre (CODA-CERVA-VAR), 17 Leuvensesteenweg, 17, B-3080 Tervuren, Belgium

$18 *$ Corresponding author: Tel.: +32 104737 35; fax: +32 104737 28. E-mail address:

19 Yvan.Larondelle@uclouvain.be (Yvan Larondelle).

21 Abstract

22 In vitro risk assessment of dietary contaminants has become a priority in human food 23 safety. In the present paper, we propose an in vitro approach associating different 24 complementary tools in an original toolbox aiming at improving the assessment of the 25 toxicological impact of dietary contaminants at realistic human exposure levels, with a 26 special focus on the intestinal compartment. The system is based on the use of four 27 complementary cellular tools, namely stress gene induction in transgenic strains of 28 Escherichia coli, modulation of the activity of key biotransformation enzymes 29 (cytochrome P-450 (CYP) 1A1 and 3A4) in a human intestinal cell line, and activation of 30 aryl hydrocarbon receptor $(\mathrm{AhR})$ and estrogenic receptor (ER)-dependent genes in 
1 agonistic and antagonistic assays with luciferase reporter cells. It was applied to four 2 chosen model molecules: ochratoxin A (OTA) and deoxynivalenol (DON), two common

3 food-borne mycotoxins, and imazalil (IMA) and benomyl (BEN), two fungicides widely

4 occurring in foodstuffs. All these assays were performed at or around a realistic intestinal

5 concentration, determined through a deterministic approach based on the calculation of a

6 theoretical maximum daily intake (TMDI). Using the four model molecules, we clearly

7 highlighted that induction of CYP1A1 activity and inhibition of CYP3A4 activity

8 occurred in Caco- 2 cells at a realistic intestinal concentration of IMA. Furthermore, some

9 bacterial stress genes were induced in a range of realistic concentrations, following

10 exposure to DON and IMA. In addition, BEN clearly provoked an ER agonistic activity

11 in a human estrogen sensitive reporter cell line. All these results are in accordance with

12 literature, suggesting that our in vitro toolbox constitutes an interesting approach in order

13 to obtain a first 'fingerprint' of dietary contaminants at realistic human exposure for

14 further risk assessment.

16 Keywords:- Food contaminants; intestine; stress genes; cytotoxicity; CYP; AhR;

17 estrogen; Caco-2 cells; ochratoxin A; deoxynivalenol; imazalil; benomyl

\section{Introduction}

20 Nowadays, the chemical safety of food is of major concern since our diet contains a wide 21 range of undesired substances. These food contaminants include for example pesticides, 22 heavy metals and persistent organic pollutants (POPs), which are widespread in the 23 environment and readily enter the food chain. In addition, food contamination may also 24 occur during food processing and cooking (e.g. benzo $[a]$ pyrene $(\mathrm{B}[a] \mathrm{P})$, acrylamide) or 25 through the release of chemicals from consumer products, such as baby toys, and 26 packaging (e.g. bisphenol A, phthalates). Furthermore, mycotoxins, secondary 27 metabolites produced by fungal species in high moisture conditions occurring in field or 28 during storage of cereals or other agricultural goods, are recovered in derived foodstuffs.

29 Due to the widespread of dietary contamination by mycotoxins, these substances are also 30 considered as an important hazard for human and animal health. 
1 Given the fact that the effects of food contaminants on human health are not always 2 thoroughly known, more investigations about their toxicity and more risk assessment 3 studies should be performed. The process of risk assessment generally integrates 4 information from both exposure assessment and hazard characterization. In order to be 5 relevant, the hazard must be characterized experimentally at realistic doses.

7 The dietary contaminants present in the gastro-intestinal tract should gain access to the 8 intestinal mucosa. There, the enterocytes, can be considered on one hand as the first 9 biological barrier encountered by the xenobiotics and, on the other hand, as a human 10 tissue submitted to high concentrations of these compounds. The large microbial 11 population present in the intestine and especially in the colon (e.g. Bacteroides, 12 Lactobacillus, Bifidobacterium, Escherichia) should also be submitted to most of the 13 dietary contaminants and could be affected. These microbes contribute to the normal 14 digestive function and, in some cases, to the transformation of dietary compounds or 15 drugs into often more readily absorbed and more or less toxic forms (Sousa et al., 2008;

16 Cani and Delzenne, 2009; Laparra and Sanz, 2010). Toxicity on bacteria may thus have 17 an impact on the bioavailability and effects of ingested chemical compounds.

19 In order to estimate realistic concentrations at the intestinal level, one has to take into 20 account the dilution of the contaminant in the alimentary bolus. In addition, the question 21 of bioaccessibility should ideally be considered as well. For assessing realistic 22 concentrations at the hepatic level, absorption and intestinal first-pass metabolism of 23 dietary compounds are also of crucial importance. Recommendations for revising current 24 risk assessment models are often stated, with the objective to reduce animal testing, to 25 improve relevance of toxicodynamic data for human health and to focus on realistic 26 exposure and toxicokinetics. Consistent with these recommendations, a package of high 27 throughput in vitro experimental tools would be necessary in order to quickly assess some 28 important toxicological effects due to the dietary contaminants at realistic exposure 29 levels. In this paper, we therefore elaborated a model toolbox comprising a set of selected 30 complementary relevant in vitro assays in bacterial and eukaryotic cell types, allowing 
1 taking a first 'fingerprint' of tested toxicants in realistic chronic exposure conditions, with

2 a special focus on the intestinal compartment.

4 In a first in vitro assay, we used reporter genes in genetically modified Escherichia coli

5 strains that respond to different types of stress (Dardenne et al., 2007; Dardenne et al.,

6 2008), in order to assess acute toxicity and give an insight into the toxic mode of action

7 of dietary compounds.

9 A second in vitro assay focused on the cytochrome P-450 (CYP) biotransformation

10 enzymes present in enterocytes. These cells are indeed the first major site for metabolism

11 prior to systemic uptake of orally ingested xenobiotics and the major catalysts of first-

12 pass metabolism in enterocytes are the CYP biotransformation enzymes, mainly the

13 CYP3A4 isoform and to a lesser extent, the CYP1A1 isoform (Prueksaritanont et al.,

14 1996; Lown et al., 1997; Lampen et al., 1998; Paine et al., 1999; Zhang et al., 1999;

15 Paine et al., 2006). However, a great inter-individual variability in the expression of these

16 CYP isoforms may be observed in the human intestine (Paine et al., 1997; Paine et al.,

17 1999; Lindell et al., 2003; Paine et al., 2006). It has been established in enterocytes as

18 well as in the Caco-2 intestinal cell line, that CYP1A1 is likely to be induced rather than

19 constitutive (Boulenc et al., 1992; Rosenberg and Leff, 1993; Buchthal et al., 1995;

20 Prueksaritanont et al., 1996), with diet clearly taking part in this induction (Fontana et al.,

21 1999). Although most CYP oxidations are involved in detoxification pathways, CYP1A1

22 also catalyzes the production of reactive cytotoxic metabolites and the activation of pro-

23 carcinogens, such as PAHs, like $\mathrm{B}[a] \mathrm{P}$, into carcinogenic DNA-binding species (Schwarz

24 et al., 2001; Shimada et al., 2001). Furthermore, some endogenous compounds are

25 metabolized by CYP1A1. It has been shown, for example, that CYP1A1 is implicated in

26 all-trans-retinoic acid (atRA) metabolism (Lampen et al., 2000; Marill et al., 2000;

27 McSorley and Daly, 2000) and 17 $\beta$-estradiol (E2) catabolism to weak estrogen (Lee et

28 al., 2003; Tsuchiya et al., 2005). Therefore, dietary regulation of CYP enzymes may

29 contribute to pathogenic mechanisms (Murray, 2006). It is also well known that CYP3A4

30 is implicated in the metabolic processing of a large range of (pro-)drugs. The co-

31 occurrence at the level of the intestinal epithelium of other compounds modulating the 
1 CYP3A4 content, such as grapefruit juice, may be detrimental (Guengerich, 1997; Lown

2 et al., 1997; Dresser et al., 2000).

3

4 The third in vitro assay focused on the aryl hydrocarbon nuclear receptor (AhR), a ligand-

5 activated transcription factor of the Per-Arnt-Sim (PAS) superfamily, which is known to

6 regulate CYP1A1 transcription. It is located in its free state in the cytosol, as a complex

7 with the chaperone proteins Hsp90, p23 and immunophilins. Ligand binding to AhR

8 triggers its nuclear translocation and fixation to the aryl receptor nuclear translocator

9 (Arnt), resulting in binding of the complex to the dioxin-responsive elements (DREs) on

10 target genes (Denison and Whitlock, 1995; Delescluse et al., 2000; Ma, 2001; Mimura

11 and Fujii-Kuriyama, 2003; Kawajiri and Fujii-Kuriyama, 2007). Several very toxic

12 dietary contaminants, like 2,3,7,8-tetrachlorodibenzo- $p$-dioxin (TCDD), have been

13 reported to bind to $\mathrm{AhR}$ and to trigger downstream target gene transcription (Denison and

14 Nagy, 2003; Ashida et al., 2008). It is now well established that, among other genes, the

15 transcription of CYP1A1, CYP1A2, UDP-glucuronosyltransferase (UGT) and

16 glutathione-S-transferase (GST) is mediated by the AhR.

18 A fourth and last in vitro assay focused on the estrogen receptor (ER), another ligand-

19 activated transcription factor, belonging to the superfamily of steroid hormone nuclear

20 receptors. ER needs ligand binding in the nucleus to trigger conformational changes and

21 to subsequently homodimerize, bind to an estrogen response element (ERE) and activate

22 transcription of its target genes (Nilsson et al., 2001). Furthermore, a cross-talk between

23 AhR and ER pathways has been established on the basis of anti-estrogenic effects of AhR

24 ligands, such as TCDD (Nilsson et al., 2001; Ohtake et al., 2008; Ohtake et al., 2009).

25 Since (i) the toxic effects of TCDD are known to be in part mediated by the AhR 26 (Mimura and Fujii-Kuriyama, 2003; Bock and Köhle, 2006), (ii) an estrogenic disruption 27 may arise from exogenous ligand binding on ER (le Maire et al., 2010), (iii) the ligand28 activated AhR complex is able to potentiate or repress either DRE or ERE target genes 29 through association with ER complex by cross-talk mechanisms (Nilsson et al., 2001; 30 Ohtake et al., 2008; Ohtake et al., 2009), (iv) the human diet contains a large amount of 
1 AhR/ER-activating substances, attention should be paid to molecules able to act on the 2 AhR/ER pathways.

4 Considered together, the four in vitro experimental tools described above constitute a 5 package of complementary tests that may be considered as an efficient toolbox allowing 6 taking a first 'fingerprint' of potential toxicants. The aim of the present work was to 7 assess the pertinence of this toolbox by applying it to four well-known dietary 8 contaminants displaying distinct toxicological effects and showing human health concern: 9 two mycotoxins, namely ochratoxin A (OTA) and deoxynivalenol (DON), and two 10 fungicides, imazalil (IMA) and benomyl (BEN). The chemical structures of these 11 compounds are shown in Figure 1.

13 OTA is produced by fungal species from the genera Penicillium and Aspergillus and 14 occurs in cereals, but also in nuts, pulses, beans, spices, dried fruits, grape(s) (juice), 15 wine, raisins, beer, cocoa products or coffee (EFSA, 2006). Furthermore, the carry-over 16 to animal offal might be important, especially in the kidney for which however the human 17 consumption is relatively limited (EFSA, 2004). It is mainly nephrotoxic in mammalian 18 species, but also immunotoxic, neurotoxic and teratogenic (EFSA, 2006). The occurrence 19 of OTA in food and human blood samples has been associated with human endemic 20 nephropathy and tumours of the upper urinary tract, in different countries (Maaroufi et 21 al., 1995; Radic et al., 1997; Stoev, 1998; Vrabcheva et al., 2000). However, due to 22 inadequate evidence in humans, OTA has been classified as possible human carcinogen 23 (group 2B) by the International Agency for Research on Cancer (IARC, 1993). One 24 debated hypothesis for the carcinogenicity of OTA in kidney implies covalent DNA 25 adduct formation after bioactivation by biotransformation enzymes (for a review, see 26 Pfohl-Leszkowicz and Manderville (2007)). DON is a trichothecene also called 27 vomitoxin, which is produced by strains of Fusarium. It is often reported in wheat, 28 barley, maize, oat, rice, rye, sorghum and triticale but also in processed food products 29 such as wheat flour, bread, beer or noodles. In humans, primary targets of DON are the 30 immune function (Pestka and Smolinski, 2005) and the mucosa of the gastro-intestinal 31 tract, which may be damaged, often resulting in gastroenteritis symptoms after acute 
1 exposure. Furthermore, genotoxic potential of DON and association with esophageal

2 cancer have been suggested (Rotter et al., 1996; Bony et al., 2006).

4 Pesticides may also be daily ingested, mainly through fruit and vegetable consumption.

5 IMA is a post-harvest imidazole fungicide mainly applied on citrus fruits. This chemical

6 is also used as broad-spectrum veterinary topical antimycotic agent under the name of

7 enilconazole (Vanden Bossche et al., 2003). IMA belongs to the group of the 10

8 pesticides the most frequently reported in fruits and vegetables by European Member

9 States (Poulsen and Andersen, 2003). The mode of action of IMA is based on the

10 inhibition of sterol demethylation, which affects membrane integrity in fungal cells

11 (Ghannoum and Rice, 1999; EFSA, 2007). Little information is available regarding the

12 toxic effects of IMA on human health. However, it seems that the liver is the primary

13 target for IMA in experimental animals (EFSA, 2007) even if IMA has also been shown

14 to act on cytochrome P450 (CYP) activity in the intestinal Caco-2 cell line (Sergent et al.,

15 2009). IMA is an inhibitor of the activity of human aromatase (CYP19), an enzyme that

16 catalyzes the conversion of androgens to estrogens; it appears to be as potent as the

17 aromatase inhibiting antiestrogen drugs used to treat breast cancer (Vinggaard et al.,

18 2000; McKinlay et al., 2008). BEN is another widely used fungicide, belonging to the

19 imidazole family. Residues of carbendazim and $n$-butylisocyanate, two degradation

20 products of BEN in soils and aqueous solutions, are commonly reported in fruits and

21 vegetables. Hepatotoxicity, teratogenicity, male reproductive toxicity and carcinogenicity

22 have been reported following exposure to BEN (Igbedioh and Akinyele, 1992; McCarroll

23 et al., 2002; Hewitt et al., 2005).

25 Practically, the proposed in vitro toolbox to be evaluated has been applied through the 26 following procedure to OTA, DON, IMA and BEN toxicity assessment at dietary realistic 27 exposure levels. At first, realistic concentrations of these contaminants occurring in the 28 gastro-intestinal tract have been calculated and cytotoxicity assessed. Secondly, the 29 effects of OTA, DON, IMA and BEN on stress genes from an intestinal bacterium and on 30 the activity of key intestinal biotransformation enzymes (CYP1A1 and CYP3A4) have 31 been investigated at realistic experimental concentrations. Since induction of CYP1A1 
1 activity is mainly mediated by the AhR pathway and considering that some toxic effects

2 may be mediated by this receptor (e.g. TCDD), we also investigated dose-dependent AhR

3 agonistic and antagonistic activities in luciferase reporter cells. Furthermore, still using

4 luciferase reporter cells, we assessed the dose-dependent agonistic and antagonistic

5 activities on the human estrogenic receptor (hER), in order to detect potential estrogenic

6 disruption by dietary contaminants mimicking estrogens. Results were systematically

7 compared with the existing literature in the discussion part, in order to validate our

8 toolbox and to propose it as an efficient tool for the screening of toxicological properties

9 of less studied dietary contaminants.

\section{Materials and methods}

\section{Determination of realistic intestinal concentrations}

13 In order to work with realistic intestinal concentrations, we have considered that the daily 14 intake of a contaminant, which is the sum of the quantity ingested through the 15 consumption of the different foodstuffs containing the substance, is diluted in the 16 alimentary bolus. This quantity ingested is obtained through the multiplication of 17 consumption and contamination data for each foodstuff susceptible to contain the 18 substance.

In the present work, we have used European consumption data from the GEMS/FOOD 21 Regional Diets (WHO, 2003). These diets, based on food balance sheet data compiled by 22 the FAO, give regional per capita average consumption [g/person/day] of raw and semi23 processed agricultural commodities. We have also used the European maximum (residue) 24 limits (M(R)Ls) for both mycotoxins (Commission Regulation (EC) $\mathrm{N}^{\circ} 1881 / 2006$ of 19 25 December 2006) and pesticides (Commission Regulation (EC) N³96/2005 of 23 26 February 2005, amended by Commission Regulation (EC) N839/2008 of 31 July 2008 27 for BEN and Commission Regulation (EU) N $\mathrm{N}^{\circ} 750 / 2010$ of 7 July 2010 for IMA) in the 28 main consumed foodstuffs as contamination data. We have then applied the concept of 29 theoretical maximum daily intake (TMDI), which assumes that a dietary chemical occurs 30 in food at the $\mathrm{M}(\mathrm{R}) \mathrm{L}$ legally authorized and that the average daily consumption of 31 foodstuffs per person corresponds to the published values from GEMS/FOOD Regional 
1 Diets. The daily intake estimated through that approach is representative of a long-term 2 exposure (WHO, 1997) (Formula 1).

$T M D I[n g /$ person $/$ day $]=\sum_{i}\left(Q_{\mathrm{E}_{i}} \cdot M(R) L_{i}\right)$

$-\mathrm{Q}_{E i}$ : consumed quantity of foodstuff $i$ in the European diet from GEMS/FOOD Regional Diets [g/person/day] $-\mathrm{M}(\mathrm{R}) \mathrm{L}_{i}$ : Maximum (residue) limit of contaminant in foodstuff $i[\mu \mathrm{g} / \mathrm{kg}]$

7 Formula 1: Theoretical maximum daily intake (TMDI) of a dietary chemical 8 contaminant

9 Dilution hypothesis of the calculated daily intake is based on the assumption that, in the

10 worst case, the dilution occurs in $1 \mathrm{~L}$ of gastro-intestinal secretions per meal, with one 11 meal per day and gives a maximal realistic intestinal concentration (C) (Formula 2).

$$
C[n g / m l]=\frac{T M D I}{V \cdot n \cdot 1000}
$$

- TMDI: theoretical maximum daily intake [ng/person/day]

- V: volume of gastro-intestinal fluid $[\mathrm{L} / \mathrm{meal}](V=1 \mathrm{~L})$

- n: number of daily meals [meals/person/day] $(n=1)$

\section{Formula 2: Maximal realistic intestinal concentration (C)}

17 Thanks to this method, we obtained a maximal realistic intestinal concentration (C)

18 representative of chronic exposure. The concentration or concentration range of OTA,

19 DON, IMA or BEN used in cellular assays were chosen to be close to or to include the 20 calculated realistic intestinal concentration of the relevant contaminant.

\section{Chemical contaminants}

23 BEN (95\%), DON (> 97\%), IMA (> 97\%), OTA (>98\%) and B[a]P were purchased 24 from Sigma-Aldrich (St Louis, MO). TCDD (99.9\%) was supplied from BCP 25 Instruments, Wellington Laboratories Inc. (Guelph, CA).

\section{Cell culture}

29 Caco-2 cells (ATCC, Rockville, MD), derived from a human colon adenocarcinoma, 30 were used between passages 26 and 34 and routinely grown in Dulbecco's Modified 
1 Eagle Medium (DMEM) (Invitrogen, Carlsbad, CA) supplemented with 10\% heat2 inactivated fetal bovine serum (FBS) (Thermo Fisher Scientific Inc., Waltham, MA), 0.1 $3 \mathrm{mM}$ non-essential amino acids (Lonza, Walkersville, $\mathrm{MD}$ ) and 2mM L-glutamine 4 (Lonza). Cells were incubated at $37^{\circ} \mathrm{C}$ in a humidified chamber with $5 \% \mathrm{CO}_{2}$, with 5 medium change every 2 days.

Stable reporter cell lines

7 Rat hepatoma H4IIE (DR-CALUX ${ }^{\circledR}$ ) (Biodetection System, NL), and human hepatoma 8 HepG2-Luc were used as dioxin sensitive reporter cells containing AhR, and human 9 breast cancer MMV-Luc cells (originating from MCF-7 cells) as estrogen sensitive 10 reporter cells containing mainly ER- $\alpha$. These three cell lines were the result of a stable 11 transformation with an inducible firefly luciferase reporter gene (Aarts et al., 1993; 12 Willemsen et al., 2004; Van der Heiden et al., 2009). H4IIE (DR-CALUX ${ }^{\circledR}$ ), HepG2-Luc 13 and MMV-Luc cells were grown respectively in Minimum Essential Medium (MEM) 14 alpha, MEM and DMEM (all from Thermo Fisher Scientific Inc.), supplemented with $1510 \%$ heat-inactivated FBS (AE scientific, Marcq, BE). DMEM was further supplemented 16 with $100 \mathrm{U} / \mathrm{ml}$ of penicillin $\mathrm{G}, 100 \mu \mathrm{g} / \mathrm{ml}$ of streptomycin (Thermo Fisher Scientific Inc.) 17 and $1 \mu \mathrm{g} / \mathrm{ml}$ of bovine pancreas insulin (Sigma-Aldrich). Cells were grown at $37^{\circ} \mathrm{C}$ in $5 \%$ $18 \mathrm{CO}_{2}$.

Bacterial strains

All strains of E. coli, a common Proteobacterium from the human gut microbiota, used in 21 the present study (KatG, Zwf, Soi28, Nfo, MicF, OsmY, UspA, ClpB, MerR, RecA, 22 UmuDC, Ada, SfiA and DinD), except SfiA, are based on an E. coli K-12 derivative SF1 23 containing the mutations lac4169 deleting the entire lac operon, and rpsL. All the 24 different LacZ fusions are present as single chromosomal inserts. The strains, described 25 in Dardenne et al. (2007), were selected from the work of Orser et al. (1995) and respond 26 to different types of stress: DNA damage, oxidative stress, protein denaturation, 27 membrane damage, osmotic stress, general cellular stress and heavy metal presence. The 28 SfiA strain is part of the SOS chromotest derived from E. coli GC4436 with a deletion in 29 the lac operon carrying a sfiA::lacZ fusion, so that responses to DNA damaging agents 30 can be measured (Quillardet and Hofnung, 1985). 
2 Cytotoxicity was assessed in the different eukaryotic cell lines. Colorimetric assays were

3 performed and cell morphology was routinely observed by phase contrast microscopy.

4 Caco-2 cells

5 The colorimetric 3-(4,5-dimethylthiazol-2-yl)-5-(3-carboxymethoxyphenyl)-2(4-

6 sulfophenyl)-2H-tetrazolium (MTS) assay purchased as a kit (Celltiter $96^{\circledR}$ AQueous One

7 Solution Cell Proliferation Assay, Promega, Madison, WI) was used. It measures cellular

8 metabolic activity as a way to assess the effect of dietary contaminants on Caco-2 cell

9 proliferation. Cells were seeded in 96-well plates at a density of $1.10^{4}$ cells $/ \mathrm{cm}^{2}$ and were

10 incubated during 48h, 24h after seeding, with OTA, DON, IMA or BEN diluted in $0.5 \%$

11 FBS-enriched culture medium at a final concentration of respectively $1 \mathrm{ng} / \mathrm{ml}, 250 \mathrm{ng} / \mathrm{ml}$,

$122500 \mathrm{ng} / \mathrm{ml}$ and $250 \mathrm{ng} / \mathrm{ml}$. Control vehicles corresponding to $0.0002 \%(\mathrm{v} / \mathrm{v})$ DMSO for

13 OTA, $0.05 \%(\mathrm{v} / \mathrm{v})$ ethanol for DON, and $0.01 \%(\mathrm{v} / \mathrm{v})$ DMSO for IMA and BEN as well

14 as negative control, consisting in $0.5 \%$ FBS-enriched culture medium alone, were also

15 tested. The MTS assay was carried out as described by the manufacturer with formazan

16 production detected at $500 \mathrm{~nm}$ (reference wavelength: $690 \mathrm{~nm}$ ) with a Spectracount

17 spectrophotometer (Packard, Warrenville, IL).

19 As another indicator of cytotoxicity, the release of cytosolic lactate dehydrogenase 20 (LDH) by damaged and necrosed cells into the extracellular medium was measured in the 21 same conditions as for the EROD assay (see below). Caco-2 cells were seeded in 48-well 22 plates at a density of $3.10^{4}$ cells $/ \mathrm{cm}^{2}$ and were cultivated until 16-day post-confluence 23 with culture medium changes three times per week. Cells were then incubated for 6 or 24 24h with OTA, DON, IMA, BEN or vehicles diluted in FBS-free culture medium at the 25 same final concentration as for the MTS assay. The negative control consisted in FBS26 free culture medium alone and the positive control, corresponding to $100 \%$ of cell 27 mortality, consisted in cells treated with $1 \%(\mathrm{v} / \mathrm{v})$ Triton $^{\circledR}$ X-100 (Sigma-Aldrich) in 28 FBS-free culture medium. The activity of LDH in the medium was determined with the 29 Cytotoxicity detection kit (Roche diagnostics, Mannheim, DE) according to the 30 manufacturer's instructions with formazan production detected at $500 \mathrm{~nm}$ (reference 31 wavelength: $690 \mathrm{~nm}$ ) with a Spectracount spectrophotometer (Packard). 
Stable reporter cells

2 The assay routinely used to test the effect of the selected chemicals on the proliferation of

3 stable reporter cells was the 3-(4,5-Dimethylthiazol-2-yl)-2,5-diphenyltetrazolium

4 bromide (MTT) colorimetric assay, which also permits to measure cellular metabolic

5 activity. H4IIE DR-CALUX ${ }^{\circledR}$, HepG2-Luc and MMV-Luc cells were seeded in 96-well

6 plates at a density of respectively 94000,31000 and $62500 \mathrm{cells} / \mathrm{cm}^{2}$, in phenol red-free

7 DMEM supplemented with 10\% heat-inactivated FBS for both H4IIE and HepG2-Luc

8 cell lines and with $10 \%$ charcoal-dextran-treated FBS, aiming at eliminating potential

9 hormones that could interfere during the assay, for the MMV-Luc cell line. MMV-Luc

10 cells were put in contact with the charcoal-dextran-treated FBS-enriched culture medium

$1124 \mathrm{~h}$ before seeding. After overnight incubation, cells were exposed during $24 \mathrm{~h}$ to serial

12 dilutions of OTA, DON, IMA or BEN, to culture medium alone, or to culture medium

13 containing $0.4 \%(\mathrm{v} / \mathrm{v})$ of the vehicle for all tested concentrations (ethanol for OTA and

14 IMA, water for DON and DMSO for BEN). Final concentrations used for the three cell

15 lines were as follows. OTA: 4, 40, 400, 4000 and $40000 \mathrm{ng} / \mathrm{ml}$. DON: 3.2, 16, 80, 400,

16 and $2000 \mathrm{ng} / \mathrm{ml}$. BEN: 64, 320, 1600, 8000, and $40000 \mathrm{ng} / \mathrm{ml}$. For IMA, two different

17 ranges of concentration were used: 312, 625, 1250, 2500, 5000, 10000, 20000, and 40000

$18 \mathrm{ng} / \mathrm{ml}$ with both the H4IIE DR-CALUX ${ }^{\circledR}$ and HepG2-Luc cell lines and 16, 125, 250,

19500 , and $4000 \mathrm{ng} / \mathrm{ml}$ with the MMV-Luc cell line. After medium removal, cells were

20 washed with $100 \mu \mathrm{l}$ phosphate buffered saline (PBS) (Oxoїd, Hampshire, UK) and

21 incubated at $37^{\circ} \mathrm{C}$ with $100 \mu \mathrm{l}$ yellow MTT reagent $(0.5 \mathrm{mg} / \mathrm{ml})$ (Sigma-Aldrich) during

22 3h. The colored insoluble formazan reagent produced by metabolically active

23 mitochondria was made soluble with DMSO and detected at $540 \mathrm{~nm}$ (reference

24 wavelength: $620 \mathrm{~nm}$ ) with a Multiskan Ascent spectrophotometer (Thermo Fisher

25 Scientific Inc.) after plate agitation during $15 \mathrm{~min}$.

27 Bacterial stress gene profiling assay

28 The entire procedure for the bacterial stress gene profiling assay is described in Dardenne 29 et al. (2007). The different E. coli strains were exposed for $90 \mathrm{~min}$ in the exponential 30 growth phase to a $1 / 2$ serial dilution of OTA $(1.6-100 \mu \mathrm{g} / \mathrm{ml})$, DON $(0.031-2 \mu \mathrm{g} / \mathrm{ml})$,

31 IMA $(0.4-13 \mu \mathrm{g} / \mathrm{ml})$ or BEN $(0.78-50 \mu \mathrm{g} / \mathrm{ml})$ or to vehicle alone, corresponding to $1 \%$ 
$1 \quad(\mathrm{v} / \mathrm{v})$ methanol for OTA and DON and 1\% (v/v) DMSO for IMA and BEN, for all tested

2 concentrations. Afterwards, the cells were lysed and the $\beta$-galactosidase activity was

3 measured.

4

5 Activity of the promoter is calculated taking into account the growth inhibition of the

6 used strain. The results are presented as fold inductions at a given dose $i$ relative to the

7 control values and were calculated through a set of formulas (Formula 3 and 4).

$$
\text { Activity }_{i}=0,19 \times\left(\frac{O D_{420 \mathrm{~nm}}^{P E}-O D_{420 \mathrm{~nm}}^{S E}}{\left(O D_{600 \mathrm{~nm}}^{P D} \times 90 \mathrm{~min}\right)+\left(\left(O D_{600 \mathrm{~nm}}^{P E}-O D_{600 \mathrm{~nm}}^{S E}\right) \times \frac{90 \mathrm{~min}}{2}\right)}\right)
$$

9 Formula 3: Activity at a given dose $i$. PE, Post exposure; SE, start exposure (=post 10 dose); PD, pre-dose (Dardenne et al., 2007).

$$
\text { Fold_Induction }=\frac{\text { Activity }_{i}}{\text { Average }_{-} \text {Activity }_{\text {negative }_{-} \text {controls }}}
$$

12 Formula 4: Fold Induction at a given dose $\boldsymbol{i}$ (Dardenne et al., 2007).

\section{2.6 Modulation of intestinal cytochrome P-450 biotransformation enzyme activity}

7-Ethoxyresorufin-O-deethylase (EROD) activity assay

15 The measurement of the EROD activity allowed us to assess the effects of the tested

16 compounds on the catalytic activity of CYP1A1 in enterocytes. Caco-2 cells were 17 inoculated at $3.10^{4}$ cells $/ \mathrm{cm}^{2}$ and cultivated until 16 days post-confluence (time of 18 maximal inducibility by $\mathrm{B}[a] \mathrm{P}$ in our experimental conditions) in 48-well plates with 19 culture medium changes 3 times per week. Cells were then incubated for 6 or $24 \mathrm{~h}$ with 20 OTA, DON, IMA or BEN diluted in FBS-free culture medium at a final concentration of 21 respectively $1 \mathrm{ng} / \mathrm{ml}, 250 \mathrm{ng} / \mathrm{ml}, 2500 \mathrm{ng} / \mathrm{ml}$ and $250 \mathrm{ng} / \mathrm{ml}$. Control vehicles 22 corresponding to $0.0002 \%(\mathrm{v} / \mathrm{v})$ DMSO for OTA, $0.05 \%(\mathrm{v} / \mathrm{v})$ ethanol for DON, and $230.01 \%(\mathrm{v} / \mathrm{v})$ DMSO for IMA and BEN were also tested. Positive controls consisted in $24 \mathrm{~B}[a] \mathrm{P}(250 \mathrm{ng} / \mathrm{ml})$ or TCDD $(0.3 \mathrm{ng} / \mathrm{ml})$ and negative control consisted in FBS-free 25 culture medium alone (untreated cells). Cells were rinsed with Hank's Balanced Salt 26 Solution (HBSS) (Lonza) and incubated for 30 minutes at $37^{\circ} \mathrm{C}$ with $300 \mu 1$ of 7 27 ethoxyresorufin $(5 \mu \mathrm{M})$ (Sigma-Aldrich) in phenol red-free DMEM (Lonza), in the 28 absence of contaminants or vehicles. Fluorescence due to the conversion of the substrate 
1 to resorufin was measured, in the supernatants, using a Fluoroskan Ascent FL fluorimeter

2 (Thermo Fisher Scientific Inc.) with excitation and emission wavelengths of 530 and 585

$3 \mathrm{~nm}$, respectively. The EROD activity was normalized to the cell protein content

4 determined with the bicinchoninic acid protein (BCA) assay kit (Sigma-Aldrich) after

5 cell lysis with $1 \%(\mathrm{w} / \mathrm{v})$ sodium deoxycholate (DOC) in water, at $\mathrm{pH}$ 11.3.

CYP3A4 activity assay

7 The CYP3A4 activity assay was used to estimate the inhibitory effect of the tested 8 compounds on the catalytic activity of CYP3A4 in enterocytes. Caco-2 cells were seeded 9 at $4.10^{4}$ cells $/ \mathrm{cm}^{2}$ in 12 -well plates pre-coated with type I collagen (Sigma-Aldrich) and

10 grown to confluence. As described by Schmiedlin-Ren et al. (1997), Caco-2 cells were 11 then cultivated during 2 weeks in 5\% FBS-enriched DMEM and in the presence of 0.5 $12 \mu \mathrm{M}$ of $1, \alpha 25-(\mathrm{OH})_{2}$-vitamin $\mathrm{D}_{3}\left(1,25\right.$-vitD $\left.{ }_{3}\right)$ (Sigma-Aldrich), in order to express 13 functional CYP3A4 activity, with culture medium changes three times per week. The last 14 day, the cells were rinsed with PBS and incubated for $3 \mathrm{~h}$ at $37^{\circ} \mathrm{C}$ with $500 \mu \mathrm{M}$ 15 testosterone, in the absence of other compound (negative control) or in the presence of 16 ketoconazole (positive control), OTA, DON, IMA or BEN diluted in Hanks' balanced 17 salt solution (HBSS) at $\mathrm{pH} 7.4$ at a final concentration of respectively $26.6 \mu \mathrm{g} / \mathrm{ml}(50$ $18 \mu \mathrm{M}), 1 \mathrm{ng} / \mathrm{ml}, 250 \mathrm{ng} / \mathrm{ml}, 2500 \mathrm{ng} / \mathrm{ml}$ and $250 \mathrm{ng} / \mathrm{ml}$. Supernatants were then collected 19 for $6 \beta-(\mathrm{OH})$-testosterone quantification through HPLC, as previously described in 20 Sergent et al. (2009). The limits of detection (LOD) and quantification (LOQ) were 100 21 and $300 \mathrm{nM}$, respectively. The CYP3A4 activity was normalized to the cell protein 22 content determined with the BCA assay kit (Sigma-Aldrich) after cell lysis with 1\% 23 (w/v) DOC in water, $\mathrm{pH} 11.3$.

\section{Human and rat aryl hydrocarbon receptor (AhR) agonistic/antagonistic activities}

26 The cell-based assays to screen for agonistic/antagonistic AhR activities of chemicals 27 were carried out as previously described (Van der Heiden et al., 2009). Briefly, 94000 28 cells $/ \mathrm{cm}^{2}$ were seeded in 96-well culture plates and incubated overnight. In assays to 29 measure AhR agonistic activities, H4IIE DR-CALUX ${ }^{\circledR}$ or HepG2-Luc cells were exposed 30 during 6 or $24 \mathrm{~h}$ to serial dilutions of OTA, DON, IMA or BEN, at the same final 31 concentrations as for the cytotoxicity assay, or to culture medium containing $0.4 \%(\mathrm{v} / \mathrm{v})$ 
1 of the vehicle for all tested concentrations (ethanol for OTA and IMA, water for DON 2 and DMSO for BEN). In assays to measure AhR antagonistic activities, the cells were 3 exposed during $24 \mathrm{~h}$ simultaneously to a constant concentration of the AhR inducer 4 TCDD (0.1 or $3 \mathrm{ng} / \mathrm{ml}$, for H4IIE DR-CALUX ${ }^{\circledR}$ and HepG2-Luc, respectively) and to 5 increasing concentrations of OTA, DON, IMA or BEN (the same range as for the 6 agonistic assay). The inducer concentration was chosen to obtain a maximal luciferase 7 activity. Solvent concentration was $0.8 \%(\mathrm{v} / \mathrm{v})$ in the culture medium for all tested 8 concentrations. In both assays (agonistic and antagonistic activities), the medium was 9 removed after incubation with the target analytes and the cells were lysed with $50 \mu 1$ of a 10 solution containing $25 \mathrm{mM}$ Tris, $2 \mathrm{mM}$ 1,4-dithio-DL-thréitol (DTT), $2 \mathrm{mM}$ trans-1,2-

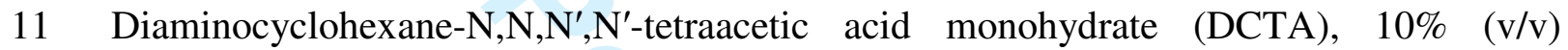
12 glycerol and 1\% (v/v) Triton X-100 (all from Sigma-Aldrich). An ORION II

13 luminometer equipped of an automatic injector (Berthold Detection System, Pforzheim, $14 \mathrm{DE})$ was used to add $100 \mu \mathrm{l}$ of a solution containing both luciferin $(0.15 \mathrm{mg} / \mathrm{ml})$ 15 (Synchem OHG, Felsberg/Altenburg, DE) and ATP (0.3 mg/l) (Roche Diagnostics), and 16 to directly measure the emission of light resulting from the luciferase activity and 17 reported as Relative Light Units (RLUs).

19 In assays to measure AhR agonistic activities, when a dose-response curve was obtained, 20 the median effective concentration $\left(\mathrm{EC}_{50}\right)$ was calculated from a non linear equation 21 (Formula 5). The relative potency (REP) of a chemical was calculated as the ratio 22 between the $\mathrm{EC}_{50}$ of the reference ligand and that of the chemical. Antagonistic activity 23 was expressed as a relative response, i.e. in percentage of the maximal cell response to 24 TCDD, corresponding to $100 \%$.

$$
y=\frac{A_{0}}{1+\left(\frac{x}{A_{1}}\right)^{A_{2}}}
$$

26 Formula 5: Non linear equation of a dose-response curve allowing determining

$27 \mathbf{E C}_{\mathbf{5 0}} \cdot \mathrm{y}$ is cell response, expressed in RLUs or in relative response (\%); $\mathrm{x}$ is the analyte 28 concentration; $\mathrm{A}_{0}$ is the maximal response expressed in RLUs or in relative response (\%); $29 \mathrm{~A}_{1}$ is $\mathrm{EC}_{50}$ and $\mathrm{A}_{2}$ is the slope of the linear part of the curve. 
1 Human estrogen receptor (hER) agonistic/antagonistic activities

2 In order to test agonistic/antagonistic hER activities of dietary contaminants, MMV-Luc

3 cells were used. These cells were put in contact with the charcoal-dextran-treated FBS-

4 enriched culture medium $24 \mathrm{~h}$ before seeding, as explained previously for the cytotoxicity

5 assays. MMV-Luc cells were then seeded in 96-well plates at a density of 22000

6 cells $/ \mathrm{cm}^{2}$ and incubated overnight. In assays to measure hER agonistic activities, MMV-

7 Luc cells were exposed during $24 \mathrm{~h}$ to serial dilutions of OTA, DON, IMA or BEN, at the

8 same final concentrations as for the cytotoxicity assay, or to the culture medium

9 containing $0.4 \%(\mathrm{v} / \mathrm{v})$ of the vehicle for all tested concentrations (ethanol for OTA and

10 IMA, water for DON and DMSO for BEN). In assays to measure hER antagonistic

11 activities, the cells were exposed during $24 \mathrm{~h}$ simultaneously to a constant concentration

12 of the hER inducer E2 $(1.4 \mathrm{ng} / \mathrm{ml})$ (Sigma-Aldrich) and to increasing concentrations of

13 OTA, DON, IMA or BEN (the same range as for the agonistic assay), or to $60.7 \mathrm{ng} / \mathrm{ml}$

$14(100 \mathrm{nM})$ of fulvestrant (Sigma-Aldrich) as a positive antagonistic control (Osborne et

15 al., 2004). The inducer concentration was chosen to obtain a maximal luciferase activity,

16 which was set at $100 \%$. Solvent concentration was $0.8 \%(\mathrm{v} / \mathrm{v})$ in the culture medium for

17 all tested concentrations.

18 The emission of light resulting from the luciferase activity was measured and data were

19 analyzed and expressed as previously described for the AhR assay.

21 Statistical analysis

22 Results were expressed in means \pm S.E.M. of three independent experiments performed 23 in triplicate $(n=9)$. Statistical analysis was conducted with the SPSS 18.0 computer 24 program (IBM, Somers, NY), using one-way analysis of variance (ANOVA) coupled 25 with post-hoc test of Scheffe or Tukey. When comparison was made with a reference 26 group, post-hoc test of Dunnett was used. When homogeneity of variance was not 27 assumed, the correction of Welch was applied and coupled with the post-hoc test of 28 Dunnett T3. Homogeneity of variance was verified with the Levene statistic. A $\log$ 29 transformation was performed to achieve normality when necessary. Significant effects 30 were determined in comparison with respective vehicle conditions. 
$1 \quad$ Results

2 Determination of realistic intestinal concentrations

3 European dietary consumption data from GEMS/FOOD Regional Diets (WHO, 2003)

4 and European M(R)Ls of contaminants legally authorized in the main consumed

5 foodstuffs have allowed us to calculate TMDIs for OTA, DON, IMA and BEN, in a

6 deterministic way. A maximal realistic intestinal concentration of each of these dietary

7 contaminants has been calculated from the dilution hypothesis of TMDI in the gastro-

8 intestinal fluid. Maximal realistic intestinal concentrations for experimental use with

9 intestinal cells have been chosen in the same range of magnitude as calculated ones,

10 which means $1 \mathrm{ng} / \mathrm{ml}(2.46 \mathrm{nM})$ for OTA, $250 \mathrm{ng} / \mathrm{ml}(840 \mathrm{nM})$ for DON, $2500 \mathrm{ng} / \mathrm{ml}$

$11(8400 \mathrm{nM})$ for IMA and $250 \mathrm{ng} / \mathrm{ml}(860 \mathrm{nM})$ for BEN. Details of calculation of the

12 TMDI and of realistic intestinal concentrations are shown in Table 1 for OTA and DON

13 and in Table 2 for IMA and BEN. For the assays with H4IIE DR-CALUX ${ }^{\circledR}$, HepG2-Luc

14 and MMV-Luc cells, as well as with E. coli strains, a range of concentrations including

15 the calculated maximal realistic intestinal concentration was used.

\section{Cytotoxicity}

18 Cytotoxicity of the contaminants has been assessed in the various cell lines by the means 19 of different colorimetric assays evaluating the metabolic activity (considered as a good 20 approximation of the cell number) during the proliferation phase (MTS and MTT) or the 21 formation of cell necrosis (LDH release in culture medium) in 16-day post-confluent 22 cells.

24 In intestinal Caco-2 cells, cytotoxicity of OTA, DON, IMA and BEN was assessed at the 25 estimated realistic intestinal concentration (see above). After $48 \mathrm{~h}$ exposure in these 26 conditions, the MTS assay revealed a significant inhibition of cell proliferation $(p<0.005)$ 27 by DON of approximately $40 \%$ in respect to untreated cells (not shown). No significant 28 effect was observed for the other contaminants in comparison with respective vehicle 29 controls (not shown). On the other hand, after 6 or 24 h exposure of 16 -day post-confluent

30 Caco-2 cells to OTA, DON, IMA or BEN at realistic intestinal concentration, LDH 31 activity in culture media of treated cells was not higher than in control untreated cells (not 
1 shown). In all cases, vehicle controls had no effect on cell proliferation or LDH release in

2 culture medium ( $<1 \%$ of positive control). No visual alterations were observed under

3 phase contrast microscope.

5 Cell viability was also assessed by the mean of the MTT assay, with the stable reporter 6 rat and human hepatoma cell lines (H4IIE DR-CALUX ${ }^{\circledR}$ and HepG2-Luc) and the stable 7 reporter human breast cancer cell line (MMV-Luc) exposed during 24h to a range of 8 concentration of OTA, DON, IMA or BEN, as described in materials and methods. The 9 percentage of reduction of cell viability was determined in respect to untreated cells. In 10 all cases, vehicle controls had not effect on cell viability. Results indicate that none of the 11 contaminants were cytotoxic for the tested cell lines at the reference calculated realistic 12 intestinal concentrations considered for this study (see above) (not shown). However, 13 significant reductions of cell viability of approximately $20 \%$ or $30 \%$ occurred 14 respectively in HepG2-Luc cells at $400 \mathrm{ng} \mathrm{OTA} / \mathrm{ml}$ and in H4IIE DR-CALUX ${ }^{\circledR}$ cells at $1540 \mu \mathrm{g}$ OTA/ml, while the MMV-Luc cell line was not significantly affected, whatever the 16 OTA concentration used. A significant reduction of cell viability was observed after 17 exposure to concentrations of DON of $400 \mathrm{ng} / \mathrm{ml}$ and $2 \mu \mathrm{g} / \mathrm{ml}$ in the three reporter cell 18 lines. This decrease was approximately of $34 \%, 20 \%$ and $28 \%$ at $400 \mathrm{ng} / \mathrm{ml}$ and of $52 \%$, $1918 \%$ and $40 \%$ at $2 \mu \mathrm{g} / \mathrm{ml}$ in, respectively, H4IIE DR-CALUX ${ }^{\circledR}$, HepG2-Luc and MMV20 Luc cells. Significant effects of IMA on cell viability were recorded at $20 \mu \mathrm{g} / \mathrm{ml}$ for 21 H4IIE DR-CALUX ${ }^{\circledR}$ cells $( \pm 24 \%$ of decrease of viability), and at $40 \mu \mathrm{g} / \mathrm{ml}$ for HepG222 Luc cells $( \pm 40 \%$ of decrease of viability). IMA was not cytotoxic in the MMV-Luc cell 23 line, in the range of concentrations tested. BEN reduced cell viability only at the highest 24 tested dose $(40 \mu \mathrm{g} / \mathrm{ml})\left( \pm 35 \%\right.$ in H4IIE DR-CALUX ${ }^{\circledR}$ and HepG2-Luc cells and $\pm 78 \%$ in 25 MMV-Luc cells).

\section{Bacterial stress gene profiling assay}

28 Prokaryotic gene expression profiles were obtained following 90 min exposure of the 29 different transgenic E. coli strains used to different concentrations of OTA (1.6 - 100 $30 \mu \mathrm{g} / \mathrm{ml})$, DON $(0.031-2 \mu \mathrm{g} / \mathrm{ml})$, IMA $(0.4-13 \mu \mathrm{g} / \mathrm{ml})$ or BEN $(0.78-50 \mu \mathrm{g} / \mathrm{ml})$. When

31 the lowest concentration of the tested range was higher than the calculated realistic 
1 intestinal concentration and if no significant effect was observed at this lowest

2 concentration, effects at lower concentrations were not investigated.

3 In the case of OTA, significant inductions of genes related to membrane (MicF) and

4 DNA (UmuDC, Ada and SfiA) damages were obtained, but only starting from $3.13 \mu \mathrm{g} / \mathrm{ml}$,

5 which represents more than 10000 times the calculated realistic intestinal concentration.

6 At concentrations of 12.5, 25 and $50 \mu \mathrm{g} / \mathrm{ml}$ clear dose-responses were observed for

7 different stress genes related to oxidative damage (KatG, Zwf, Soi28 and Nfo), membrane

8 damage and general cell stress (MicF, OsmY, UspA and $C l p B)$ and DNA damage

9 (UmuDC, Ada, DinD and SfiA) (not shown). In the same way, no significant inductions of

10 stress genes were found after exposure of the transgenic E. coli strains to BEN at the

11 lowest tested concentration $(0.78 \mu \mathrm{g} / \mathrm{ml})$, representing more than 3 times the calculated

12 realistic intestinal concentration. At higher concentration $(12.5 \mu \mathrm{g} / \mathrm{ml})$, significant

13 inductions were revealed for endpoints related to membrane damage $(\mathrm{MicF})$ and general

14 cell lesions induced by protein perturbation $(C l p B)$ (not shown). Regarding DON, only

15 one marker for DNA damage (DinD) was induced upon exposure to the calculated

16 realistic intestinal concentration of $250 \mathrm{ng} / \mathrm{ml}$ (Figure 2A). Furthermore, at a

17 concentration ten times higher, significant induction for $\operatorname{RecA}$, which is part of the SOS

18 response, was found. E. coli strains were also sensitive to IMA. At $2500 \mathrm{ng} / \mathrm{ml}$, the

19 realistic intestinal concentration, statistically significant inductions were found for

20 markers related to protein perturbation, membrane integrity and osmotic stress (MicF and

$21 \mathrm{ClpB})$ and oxidative stress (Zwf, Soi28 and SfiA) (Figure 2B).

22

\section{Modulation of intestinal cytochrome P-450 biotransformation enzyme activity}

24 Induction of CYP1A1 activity

25 The effect of OTA, DON, IMA and BEN at calculated realistic intestinal concentration

26 (see above) on CYP1A1 activity in Caco-2 cells after 6 and 24h exposure is illustrated in

27 Figure 3. While OTA, DON and BEN had no effect, IMA revealed to be a significant

28 time-dependent CYP1A1 inducer $(p<0.005)$, with a stronger induction after 24 than $6 \mathrm{~h}$

29 exposure. Vehicle controls had no inductive effect on CYP1A1 activity in comparison

30 with untreated cells (not shown).

$31 \quad$ Inhibition of CYP3A4 activity 
1 The inhibitory effect of OTA, DON, IMA and BEN on CYP3A4 has been tested in Caco-

22 cells previously treated during 14 days with $1,25-v i t D_{3}$, in order to express functional

3 CYP3A4 activity (Schmiedlin-Ren et al., 1997). The cells were then exposed during $3 \mathrm{~h}$

4 simultaneously to $500 \mu \mathrm{M}$ of testosterone and to OTA, DON, IMA or BEN at the

5 estimated realistic intestinal concentration (see above). The quantity of $6 \beta-(\mathrm{OH})$ -

6 testosterone secreted was then measured in the cell medium. The test revealed a strong

7 inhibition of CYP3A4 activity by IMA $(p<0.05 ; \pm 60 \%$ in respect to negative control

8 consisting in untreated but pre-induced cells), as strong as by ketoconazole (positive

9 control). The activity levels achieved were down to the value measured with non-induced

10 cells, representing the basal CYP3A4 activity without preliminary induction with 1,25-

$11 \operatorname{vitD}_{3}$ (Figure 4). Other contaminants (OTA, DON and BEN) as well as vehicle controls

12 had no significant inhibitory effect on CYP3A4 activity.

\section{Human and rat aryl hydrocarbon receptor (AhR) agonistic/antagonistic activities}

15 Exposure of dioxin-responsive cells (H4IIE DR-CALUX ${ }^{\circledR}$ and HepG2-Luc) to the 16 reference ligand (TCDD) during $24 \mathrm{~h}$ resulted in a dose-response relationship (not 17 shown). The median effective concentrations $\left(\mathrm{EC}_{50}\right)$ were 0.004 and $0.5 \mathrm{ng} \mathrm{TCDD} / \mathrm{ml}$ in 18 H4IIE DR-CALUX ${ }^{\circledR}$ and HepG2-Luc cells, respectively, showing the higher sensitivity 19 to TCDD of rat hepatoma cells compared to human hepatoma cells. Time exposure (6h $v s$ 20 24h) did not change the cell sensitivity to TCDD (not shown).

21 H4IIE DR-CALUX ${ }^{\circledR}$ or HepG2-Luc stable reporter cells were exposed to a range of 22 concentrations of OTA, DON, IMA or BEN during 6 and 24h. No luciferase activity, 23 resulting from the activation of the AhR, was observed.

25 In antagonistic assays, H4IIE DR-CALUX ${ }^{\circledR}$ or HepG2-Luc cells were exposed during 26 24h simultaneously to TCDD and a range of concentrations of OTA, DON, IMA or BEN.

27 No AhR antagonistic activity was observed for none of the tested chemicals at the 28 reference concentrations considered in this paper, which are the realistic intestinal 29 concentrations, as well as at all non cytotoxic concentrations tested.

30 In all cases, vehicle controls had no effect on AhR activation. 
1 Human estrogen receptor (hER) agonistic/antagonistic activities

2 Exposure of MMV-Luc cells to the reference ligand E2 during 24h resulted in a dose-

3 dependent relationship (Figure 5), with an $\mathrm{EC}_{50}$ of $0.003 \mathrm{ng} / \mathrm{ml}$. Fulvestrant (ICI 182,

4 780) is a high affinity ER antagonist (Osborne et al., 2004). As a control, the antagonistic

5 activity was assayed in cells simultaneously exposed to E2 $(1.4 \mathrm{ng} / \mathrm{ml})$ and fulvestrant

$6(60.7 \mathrm{ng} / \mathrm{ml})$. A $93 \%$ inhibition of the E2-related induction was observed, confirming the

7 antagonistic activity of fulvestrant in MMV-Luc cells, while no cytotoxic activity was

8 evidenced using the MTT assay (not shown).

10 OTA, DON and IMA showed no hER agonistic activity in MMV-Luc cells exposed 11 during $24 \mathrm{~h}$ to the range of concentrations. On the contrary, we obtained a dose-response 12 relationship when cells were exposed to $\mathrm{BEN}$ with an $\mathrm{EC}_{50}$ of $475 \mathrm{ng} / \mathrm{ml}$ (Figure 5). The 13 REP of BEN expressed as the ratio between the $\mathrm{EC}_{50}$ of $\mathrm{E} 2$ and $\mathrm{BEN}$ was therefore 6.3 $1410^{-6}$. At the reference concentration considered in this paper, which is the realistic 15 intestinal concentration $(250 \mathrm{ng} / \mathrm{ml})$, the in vitro estrogenic activity of BEN was 16 equivalent to the effect produced by the $\mathrm{EC}_{50}(0.003 \mathrm{ng} / \mathrm{ml})$ of $\mathrm{E} 2$.

17 In antagonistic assays, MMV-Luc cells were exposed during $24 \mathrm{~h}$ simultaneously to E2 18 and a range of concentrations of OTA, DON, IMA or BEN. In these conditions, none of 19 the tested contaminants were able to decrease the relative response induced by E2 at non 20 cyototoxic concentrations.

21 In all cases, vehicle controls had no effect on hER activation.

\section{Discussion}

24 In the present paper, different cellular responses to four selected dietary chemical 25 contaminants (OTA, DON, IMA and BEN) were assessed at realistic human exposure. A 26 comparison of the results obtained with those from the literature has been performed in 27 order to validate and propose this methodology as a suitable toolbox to take a first in vitro 28 'fingerprint' of less studied dietary toxicants for risk assessment studies.

29 Since in risk assessment studies hazard characterization of dietary chemicals should 30 ideally be performed at exposure levels representative of 'normal consumers', we have 31 first proposed a methodology allowing the estimation of maximal realistic concentrations 
1 of dietary contaminants occurring in the gastro-intestinal tract by using a dilution

2 hypothesis of the ingested daily intake in the intestinal lumen. The deterministic approach

3 followed allowed us to easily mimic intestinal chronic exposure with in vitro systems to a

4 broad range of contaminants, including those for which no ADI/TDI has been established

5 and no databases necessary in a probabilistic approach are available. The theoretical

6 maximum daily intake (TMDI) has been obtained by multiplication of European maximal

7 authorized level of contaminants in foodstuffs (contamination data) with average adult

8 daily consumption data of these foodstuffs from GEMS/FOOD Regional Diets, which are

9 based on national Food Balance Sheets. Data from GEMS/FOOD Regional diets greatly

10 underestimate short-term high percentile intakes. They are used in chronic exposure

11 assessment by the Joint Meeting on Pesticide Residues (JMPR) and the Joint FAO/WHO

12 Expert Committee on Food Additives (JECFA), according to internationally accepted

13 methodologies (WHO, 1997), in order to assess long-term risks at the international level.

14 This method permits thus a valid comparison of TMDI with the 'Acceptable Daily

15 Intake' (ADI, for pesticides) or 'Tolerable Daily Intake' (TDI, for other contaminants),

16 which are based on long-term food consumption habits.

18 This very simple deterministic method, called 'by point estimates', has the particularity

19 not to be associated with any measurement of confidence and to slightly over-estimate

20 actual exposure, since it assumes that all individuals consume the same quantities of

21 specified foodstuff(s) and that the contaminant is always present in the foodstuff(s) at a

22 high level (Kroes et al., 2002). On the other hand, as compared to the probabilistic

23 approach, which is based on distributions rather than on single-point values, it requests

24 less extensive databases and offers more easily interpretable results (Claeys et al., 2008).

25 It is therefore commonly used as a first step in exposure assessment and most appropriate

26 for screening purposes (Verger, 2006), in accordance with our study. The probabilistic

27 method is indeed very useful when the first deterministic estimation is at or above

28 ADI/TDI, since it allows to refine the assessment and to better evaluate if the chemical

29 exposure is a public health issue. Whatever the approach used, it should be kept in mind

30 that the quantity of contaminant residues effectively occurring in food can be lower than

31 in raw materials after processing and/or storage (Kroes et al., 2002). 
1 In the present study, the main sources of ingestion of OTA, DON, IMA and BEN for

2 which European $\mathrm{M}(\mathrm{R}) \mathrm{Ls}$ in foodstuffs exist, have been taken into account in the 3 calculation of TMDI. For OTA, European MLs in cereal-based products, contributing to $450-70 \%$ of the dietary intake (Petzinger and Ziegler, 2000), dried vine fruit, coffee and 5 wine have been considered, while for DON, European MLs in cereal-based products were 6 the only ones to be used. The exposure assessment has resulted in a daily intake for OTA 7 and DON of respectively $13.05 \mathrm{ng} / \mathrm{kg}$ bw/day, representing 76\% of TDI (considering that 8 TWI is equally spread over the week) and $2.37 \mu \mathrm{g} / \mathrm{kg}$ bw/day, or $237.7 \%$ of TDI. The fact 9 that TMDI exceeds TDI may be explained by the crude over-estimation induced by the 10 method. It is a preliminary indication that a potential risk should be taken into account 11 and that a more precise exposure assessment should be performed, for example with the 12 probabilistic method. By comparison, the European Scientific Cooperation (SCOOP) 13 tasks on mycotoxins give estimated daily intakes of $0.1-3.5 \mathrm{ng} / \mathrm{kg}$ bw/day for OTA and $14 \quad 0.078-0.48 \mu \mathrm{g} / \mathrm{kg}$ bw/day for DON, for participating member states displaying the lowest 15 and highest mean exposure (EC, 2002; EC, 2003). For OTA, other studies report dietary 16 exposure of 2-3 ng/kg bw/day for the average adult consumer (EFSA, 2006) or 0.7-4.6 $17 \mathrm{ng} / \mathrm{kg}$ bw/day for average consumers and 6-8 $\mathrm{ng} / \mathrm{kg}$ bw/day for high consumers (SCF, 18 1998). In 2002, JECFA published a report where a probabilistic approach with French 19 data resulted in an intake of $92 \mathrm{ng}$ OTA/kg bw/week (or $13.14 \mathrm{ng} / \mathrm{kg}$ bw/day) for 20 consumers of cereals at the $95^{\text {th }}$ percentile. Regarding DON, an estimation of the dietary 21 intake ranged from $0.77 \mu \mathrm{g} / \mathrm{kg}$ bw/day with the African diet to $2.4 \mu \mathrm{g} / \mathrm{kg}$ bw/day with the 22 Middle Eastern diet (WHO, 2001).

24 The oral exposure of human to IMA and BEN through consumption of contaminated 25 fruits and vegetables has been assessed in the present study to respectively $17.47 \mu \mathrm{g} / \mathrm{kg}$ $26 \mathrm{bw} /$ day and $3.34 \mu \mathrm{g} / \mathrm{kg}$ bw/day and represents respectively $58.2 \%$ and $3.3 \%$ of their ADI.

27 In a study based on a Belgian pesticide monitoring program, the authors calculated an 28 exposure for the $97.5^{\text {th }}$ percentile consumer reaching $\pm 25 \%$ and $\pm 2 \%$ of ADI for IMA and 29 BEN, respectively (Claeys et al., 2008). In USA, the exposure to IMA was estimated to $30 \quad 0.05 \mu \mathrm{g} / \mathrm{kg}$ bw/day, in the worst case, by considering residue data in products prepared as 31 for consumption (Dougherty et al., 2000). In the case of IMA, an overestimation of the 
1 actual exposure by our methodology may be caused by the fact that residues are mainly

2 located in the peel of citrus fruits, often removed before consumption.

4 The dilution model of calculated TMDI in the gastro-intestinal fluid used in the present 5 work to generate realistic intestinal concentrations does not take into account inter6 individual variations, which can obviously influence the amount of contaminants released 7 from the food matrix in the gastrointestinal tract during the digestion process and 8 accessible for intestinal absorption (i.e. gastric and intestinal lumen volume, rate of saliva 9 secretion, rate of pancreatic or biliary secretions, composition of these secretions). In 10 addition, the approach chosen in the present study does not at all allow estimating the 11 concentrations of the contaminants in the body fluids. The concentration of the 12 contaminant in the blood depends on individual-specific factors including the proportion 13 of contaminant absorbed by intestinal cells and released in the bloodstream, the first-pass 14 metabolism in intestinal and liver cells, the excretion back towards the lumen, the half15 life and the degree of serum binding (mainly albumin), which can reach more than $99 \%$ 16 in the case of OTA (Ringot et al., 2006). The literature gives a few data for the presence 17 of contaminants in biological fluids. Depending on the study, the occurrence of OTA in 18 human blood ranged from 0.2 to $0.88 \mathrm{ng} / \mathrm{ml}$ (Studer-Rohr et al., 2000), from 0.17 to 0.56 $19 \mathrm{ng} / \mathrm{ml}$ (EFSA, 2006) or from 0.18 to $1.19 \mathrm{ng} / \mathrm{ml}$ (EC, 2002), concentrations very close to 20 the calculated realistic intestinal concentration of the present study ( $1 \mathrm{ng} / \mathrm{ml})$. In humans, 21 the concentration of DON in blood is poorly documented, while in urines, some authors 22 found mean levels of $37 \mathrm{ng} / \mathrm{ml}$ and $12 \mathrm{ng} / \mathrm{ml}$, respectively in high and low-risk areas in 23 China (Meky et al., 2003). To our knowledge, concentrations of IMA and BEN in human 24 body fluids have never been measured.

As a prerequisite to in vitro assays, the cytotoxicity of OTA, DON, IMA and BEN was 27 assessed and further experiments were performed at non-cytotoxic concentrations. DON 28 revealed to be toxic in almost all cell types, even at realistic intestinal concentration (250 $29 \mathrm{ng} / \mathrm{ml}$ ) with proliferating Caco-2 cells. The inhibition of cell proliferation by DON in 30 intestinal cell lines was already shown in similar conditions of exposure (Maresca et al., 31 2002; Kouadio et al., 2005; Bony et al., 2006; Sergent et al., 2006; Van De Walle et al., 
1 2008), whereas in the HepG2 cell line, an $\mathrm{IC}_{50}$ of $8.4 \mu \mathrm{g} / \mathrm{ml}$ has been calculated (Cetin

2 and Bullerman, 2005), suggesting that these cells are less sensitive to DON than Caco-2

3 cells. In the present study, a realistic exposure of 16-day post-confluent Caco-2 cells to

4 DON has not resulted in a marked increase of LDH release, a marker of cell necrosis. On

5 the contrary, cytotoxicity tests performed with DON in the intestinal cell line HT-29-D4,

6 showed a very slight but significant increase of LDH release (less than 2.5\%) from $10 \mathrm{nM}$

$7 \quad(2.96 \mathrm{ng} / \mathrm{ml})$, while $100 \mu \mathrm{M}$ of DON $(29 \mu \mathrm{g} / \mathrm{ml})$ was necessary to strongly increase LDH

8 release (642\% of control value), induce cellular apoptosis and diminish protein content

9 (Maresca et al., 2002). Intestinal necrosis is indeed a major toxic effect of DON. In vivo,

10 the ingestion of contaminated food with high doses of DON may create lesions of the

11 mucosa in the gastrointestinal tract, resulting in extensive hemorrhage, vomiting and

12 gastroenteritis symptoms (Pestka and Smolinski, 2005). The cytotoxicity of DON has

13 often been attributed to the inhibition of protein synthesis, by impairment of the peptidyl-

14 transferase on the $60 \mathrm{~S}$ ribosomal subunit. As a translational inhibitor binding to

15 ribosomes, DON rapidly activates the double-stranded RNA-activated protein kinase R

16 (PKR) and the downstream mitogen-activated protein kinase (MAPK) cascades, which

17 drive apoptosis as well as activation of transcription factors implicated in the

18 inflammatory pathway (Zhou et al., 2003; Pestka and Smolinski, 2005; Van De Walle et

$19 a l ., 2008)$. This overall process is called 'ribotoxic stress response'. The impact of DON

20 on cell viability was furthermore explained by pointing mitochondria and lysosomes as

21 targets, by showing an inhibition of protein and DNA synthesis, as well as through lipid

22 peroxidation (Kouadio et al., 2005; Kouadio et al., 2007). Interestingly enough, we

23 observed that the E. coli strain transfected with the promoter $\operatorname{Din} D$, responsive to DNA

24 damage, was induced at calculated realistic intestinal concentration. Furthermore, at a

25 concentration ten times higher, significant inductions for $\operatorname{RecA}$, part of the SOS response,

26 were found. These results are in accordance with the genotoxic potential attributed to

27 DON (Rotter et al., 1996; Bony et al., 2006). In addition to information about its mode of

28 action, this assay suggests that the toxicity of DON towards bacteria at realistic exposure

29 may imbalance gastro-intestinal populations, which may, on one hand, impair the

30 metabolism and bioavailability of food compounds and xenobiotics, and, on the other

31 hand, modify the systemic effects of the gut microbiota. 
1 At realistic intestinal concentration, no cytotoxicity of OTA has been highlighted in 2 intestinal cells. Sensitivity of intestinal cells to OTA toxicity has yet been shown in vitro 3 but at higher concentrations than those used in the present work (Berger et al., 2003; 4 Creppy et al., 2004). The kidney is generally considered as the first and major organ 5 affected by OTA. Nevertheless, the $\mathrm{IC}_{50}$ calculated in intestinal cells are often lower than 6 in other studies using renal cells, suggesting that the kidney has no specific sensitivity 7 towards OTA-induced cytotoxicity in comparison with cells of other origin (Creppy et 8 al., 2004; Kamp et al., 2005), even if nephropathy is the main in vivo reported effect. The 9 unchanged levels of LDH activity between control and OTA-treated intestinal cells, 10 confirmed by Berger et al. (2003), suggest that OTA does not induce cell necrosis in the 11 intestine at realistic intestinal concentration. Kamp et al. (2005) observed OTA12 dependent oxidative DNA damage, suggesting that oxidative stress plays an important 13 role in OTA-derived toxicity/carcinogenicity in the kidney, whereas another hypothesis 14 for OTA carcinogenicity suggests covalent DNA adduct formation (for a review, see 15 Pfohl-Leszkowicz and Manderville (2007)). In the present study, bacterial stress genes 16 related to membrane, DNA and oxidative damage are significantly induced at high 17 concentration. The inductions of SfiA and Nfo more specifically suggest oxidative DNA 18 damage (Dardenne et al., 2008).

IMA revealed no cytotoxicity in eukaryotic cell lines in a realistic range of 21 concentrations. Little information is available regarding toxic effects of IMA. Different 22 studies have established oral $\mathrm{LD}_{50}$ in rat ranging from 227 to $664 \mathrm{mg} / \mathrm{kg}$ bw. It seems that 23 the liver is the primary target for IMA in experimental animals (EFSA, 2007) and a time24 dependent cell death, accompanied by the depletion of intracellular ATP, GSH and 25 protein thiols, was observed in isolated rat hepatocytes by Nakagawa and Moore (1995).

26 These authors have suggested that cytotoxicity caused by IMA might be related to lipid 27 peroxidation, due to an oxidative stress, as well as to the depletion of ATP via 28 impairment of the mitochondrial function. In the present study, we have shown in the 29 prokaryotic gene expression profile of IMA that significant inductions of genes related to 30 cellular and osmotic stress, as well as to oxidative stress, occur at realistic gastro31 intestinal exposure. These results are in accordance with the hypothesis that IMA 
1 provokes an oxidative stress, as suggested by Nakagawa and Moore (1995). As a

2 consequence of the toxicity of a realistic dose of IMA on gastro-intestinal bacteria, an

3 imbalance of bacterial populations and/or a change in metabolism in the lumen may

4 occur.

5

6 The fungicide BEN commonly induces hepatotoxicity (Igbedioh and Akinyele, 1992;

7 McCarroll et al., 2002). However, in the present study, none of the tested cell lines

8 showed reduced viability in a biological realistic range of concentrations. In a study

9 performed with the HepG2 cell line, Dierickx (1999) observed a reduced cell viability at

10 a non-physiological concentration of BEN, similar to the concentration showing reduced

11 viability of HepG2-Luc cells in the present work. He attributed the observed effects to the

12 butylcarbamoyl group of BEN. Interestingly enough, an in vivo study (Banks and

13 Soliman, 1997) has shown that a 7-day treatment of rats significantly increased lipid

14 peroxidation and depleted liver GSH levels, suggesting that the hepatotoxicity induced by

$15 \mathrm{BEN}$ or its metabolites is due to an oxidative stress of cellular membranes. In the present

16 work, even though no response was recorded in the bacterial gene expression assay at

17 realistic concentration, significant inductions were observed at higher concentrations for

18 membrane damage-related endpoints, supporting the idea that lipid peroxidation may be

19 one of the modes of action of BEN.

21 Once absorbed from the lumen into intestinal cells, chemicals may undergo first-pass

22 metabolism. CYPs are major actors of these biotransformations. The study of the effects

23 of dietary chemicals on CYP expression and/or activity is of primary importance in the

24 comprehension of mechanisms of adverse and beneficial interactions in cells (Sergent $e t$

25 al., 2008). Since CYPs have often broad substrate specificities, their induction by one

26 chemical may result in enhanced metabolism of other chemicals or drugs, thereby,

27 altering their bioavailability, pharmaco- or toxicokinetic properties as well as pharmaco-

28 or toxicodynamic effects (Ma, 2001).

29

30 As in a previous publication from our group (Sergent et al., 2009), we have again

31 highlighted that IMA, which is commonly recovered in consumed fruits and vegetables, 
1 induced CYP1A1 activity at realistic exposure in intestinal Caco-2 cells. However, we

2 have not shown an AhR-mediated agonistic activity of IMA with the reporter gene assay.

3 Our results are in accordance with those of a screening study on 200 pesticides with 4 mouse hepatoma (Hepa1c1c7) cells stably transfected to obtain dioxin-responsive

5 luciferase reporter cells (Takeuchi et al., 2008). This suggests that the classical AhR

6 pathway does not mediate the induction of CYP1A1 activity by IMA. An alternative

7 CYP1A1 regulation pathway, involving PPAR- $\alpha$, another ligand-activated transcription

8 factor, and two PPAR response elements (PPRE) sites located within the CYP1A1

9 promoter gene, has been proposed in Caco-2 cells (Sérée et al., 2004; Fallone et al.,

10 2005). Since it was previously observed that IMA is able to induce PPAR- $\alpha$-mediated

11 transcriptional activity in reporter cells (Takeuchi et al., 2006), the PPAR- $\alpha$-mediated

12 CYP1A1 regulation pathway might be considered as potentially responsible for the 13 observed induction of CYP1A1 activity by IMA in Caco-2 cells. The induction of

14 CYP1A1 activity by IMA has been previously demonstrated in the small intestine and 15 liver of rats as well as in Caco-2 cells (Muto et al., 1997; Sergent et al., 2009). However, 16 Sergent et al. (2009) have suggested that a post-transcriptional pathway, acting on the 17 protein rather than on the gene expression, is involved in the increase of CYP1A1 activity 18 following exposure of Caco-2 cells to IMA.

OTA, DON and BEN had no inductive effect on CYP1A1 activity at realistic intestinal

21 concentration. In accordance with these results, no AhR-mediated agonistic activity was 22 observed in the present study after exposure of reporter cells to different concentrations 23 of these contaminants. In the same trend, Takeuchi et al. (2008), who screened 200 24 pesticides with mouse hepatoma (Hepa1c1c7) cells stably transfected to obtain dioxin25 responsive luciferase reporter cells, did not observe any $\mathrm{AhR}$ agonistic activity after 26 exposure to BEN. However, induction of CYP1A1 activity and expression by BEN and 27 its derivative carbendazim have been demonstrated in HepG2 cells and rabbit 28 hepatocytes, but at concentrations much higher than those used in the present study (Rey29 Grobellet et al., 1996; Dierickx, 1999). 
1 It is well known that CYP1A1 is implicated in the conversion of pro-carcinogens from

2 the PAH family to reactive cytotoxic metabolites, such as carcinogenic DNA-binding 3 species (Schwarz et al., 2001; Shimada et al., 2001). An induction of CYP1A1 activity by

4 another compound, such as IMA in the present case, might further provoke either pro-

5 carcinogen activation or detoxification by hydroxylation. Toxicity $v s$ protection resulting

6 from CYP1A1 induction appears to depend on the cellular context, such as carcinoma

7 cells $v s$ intact animal (Uno et al., 2004), to tissue- or cell type- specificities as well as to

8 the involvement of phase II metabolism (Nebert et al., 2004). This comment emphasizes

9 the extreme care that has to be taken in the extrapolation of in vitro results to the in vivo

10 situation. Furthermore, it is difficult to conclude about consequences of CYP1A1

11 induction since other effects may arise in parallel, such as inhibition of TCDD-induced

12 CYP1A1 activity by IMA in Caco-2 cells, suggesting cytoprotective effects towards pro-

13 carcinogen activation (Sergent et al., 2009).

15 In addition to xenobiotic metabolism, the CYP1A1 isoform is also involved in the 16 transformation of endobiotic compounds, such as atRA, the active metabolite of retinol 17 (vitamin A) (Lampen et al., 2000) and E2, which is known to act both as a promoter of 18 cell proliferation and as a pro-carcinogen (Tsuchiya et al., 2005; Parl et al., 2009). The 19 induction of CYP1A1 activity may thus lead in the disruption of atRA biological 20 activities, as well as in the resistance at the target site when atRA is used clinically. It 21 may also increase the metabolism of E2 to weak estrogenic (Oh and Chung, 2006), but 22 potentially toxic metabolites (Tsuchiya et al., 2005; Parl et al., 2009). Therefore, 23 intestinal CYP1A1 inducers, such as IMA, may influence the atRA and E2 small 24 intestinal metabolism and action.

26 Results from the present work confirm previously published material (Sergent et al., 27 2009) that shows a strong inhibition of CYP3A4 activity by a realistic concentration of 28 IMA in 1,25-vitD 3 -induced Caco-2 cells, but at lower concentration than ketoconazole, a 29 known CYP3A4 inhibitor in this cell line (Gibbs et al., 2000; Hou et al., 2007). The 30 inhibition of the CYP3A4 activity but not gene transcription by IMA has been previously 31 observed in Caco-2 cells by Sergent et al. (2009). On the other hand, the induction of 
1 CYP3A4 activity and expression, as well as the activation of the human pregnane $\mathrm{X}$ 2 receptor (hPXR), by IMA have been previously demonstrated (Muto et al., 1997;

3 Lemaire et al., 2006b). A broad range of drugs, carcinogens, but also endogenous steroids

4 (testosterone, progesterone, androstenedione, and cortisol) or E2 are substrates of

5 CYP3A4 (Guengerich, 1999; Goodwin et al., 2002) and thus good candidates for

6 interactions at the intestinal level. Since more than the half of the existing drugs is

7 metabolized by CYP3A4, interactions with drugs constitute the main issue when foreign

8 compounds modulate CYP3A4 activity. For example, an increase of bioavailability and

9 plasma concentration of felodipine or of the pro-drug terfenadine, due to the diminution

10 of oxidation by CYP3A4 inhibitors such as grapefruit juice or ketoconazole, has been

11 associated with detrimental effects. On the other hand, it has been demonstrated that the

12 CYP3A4 inhibitor ketoconazole increases oral bioavailability of concurrently

13 administered cyclosporine and reduces the dosage required (Guengerich, 1997; Dresser et

14 al., 2000). Therefore, the co-occurrence at the intestinal level of IMA and a CYP3A4-

15 substrate drug may alter its efficiency, either adversely or positively, by pre-systemic

16 metabolism. In addition, the inhibition of CYP3A4 activity by IMA may have an impact

17 on the metabolism of food contaminants, since CYP3A4 activates some PAH

18 dihydrodiols (Shimada et al., 2001), as well as pro-carcinogens, such as aflatoxin B1

19 (AFB1) (Shimada and Guengerich, 1989; Guengerich and Shimada, 1998), but at

20 relatively high substrate concentration (Gallagher et al., 1994).

22 The ability of BEN to display hER agonistic activity, even at realistic gastro-intestinal

23 concentration, has been demonstrated in the present paper. The activation of the 24 transcription of the firefly luciferase reporter gene probably occurs after the binding of 25 the dimer complex 'ligand (BEN) - receptor (ER)' to the ERE elements present in the 26 vitellogenin promoter of the MMV-Luc cell line. An agonistic effect of BEN towards 27 ER $\alpha$ has indeed been reported previously in reporter HeLa cells (Lemaire et al., 2006a).

28 Furthermore, BEN was previously shown to bind the recombinant $\mathrm{hER} \alpha$ in a binding 29 assay (Scippo et al., 2004). The estrogenicity of BEN and its degradation product 30 carbendazim was also shown to act via the induction of the aromatase CYP19 activity, 31 catalyzing the conversion of androgens to estrogens, in a human ovarian granulose-like 
1 tumor cell line (Morinaga et al., 2004). Therefore, it is likely that BEN acts as an

2 estrogenic compound by affecting both the action of estrogens, through binding to ER $\alpha$

3 and activation of ERE downstream genes, and the synthesis of estrogens, by increasing

4 estrogens level. We therefore suspect that BEN acts as an endocrine disruptor, which may

5 lead to estrogen-mediated pathologies such as reproductive disorders.

7 The overall toolbox approach proposed in this paper and including four types of in vitro 8 assays revealed to be interesting in assessing chemical risks at the intestinal level upon 9 dietary consumption. In a first assay, genetically modified E. coli strains responding to 10 different types of stress permitted to assess toxicity on bacteria present in the human gut, 11 potentially leading to an imbalance in the populations and a modification of their activity 12 and in turn impacting the digestive function, the absorption and more generally some of 13 the various effects of the microbiota on the human health. The second in vitro assay 14 performed with intestinal Caco-2 cells allowed to give a quick insight into the modulation 15 of the activity of CYP1A1 and CYP3A4 in small intestinal cells. The third and fourth in 16 vitro assays focused on the AhR and ER, respectively. Whereas the AhR is undoubtedly 17 present in human enterocytes (Fallone et al., 2004), controversy remains regarding the 18 presence of the ER. Nevertheless, ER has been identified and localized in the mouse 19 small intestine (Kawano et al., 2004) and in the human colon (Singh et al., 1998).

20 Furthermore, its expression has been associated with a lower incidence of small intestinal 21 tumorigenesis in mice (Giroux et al., 2008) and estrogen exposure in women results in a 22 reduction in colon cancer risk (Grodstein et al., 1999). In addition, recently, the decrease 23 of permeability of the intestinal barrier by ER agonists, including E2, has been 24 demonstrated both in rodents and in intestinal cell lines, such as Caco-2 (Braniste et al., 25 2009; Looijer-van Langen et al., 2011). AhR- or ER-mediated (ant)agonism by dietary 26 chemical compounds reaching the intestinal barrier at high concentration might therefore 27 have important consequences for human health.

28 The proposed toolbox is a first inititative to associate different complementary, friendly29 to-use and relevant tools. It may be further improved in the future with additional 30 approaches such as the inclusion of an in vitro simulated digestion of dietary chemicals 
1 followed by absorption studies on intestinal cells, of inhibitory assays on CYP1A1 or

2 through the use of intestinal luciferase reporter cells responding to AhR and ER ligands.

\section{Conclusions}

5 In the present work, we have proposed a package of in vitro experimental tools, which

6 responded to chemical stresses and proved to be efficient in assessing some relevant

7 dietary toxicological effects, even at realistic contaminant exposure in humans, as shown

8 by the comparison of the results obtained with four well-known contaminants with those

9 from the literature. Due to its high contribution in first-pass metabolism, as well as in the

10 bioavailability of dietary compounds, the intestinal compartment was the major focus of

11 the present study. Therefore, a method of easy evaluation of realistic concentrations of

12 dietary contaminants occurring in the human gastro-intestinal tract was proposed. This

13 method can be applied to a large range of dietary chemicals for which limited data exist

14 and is relevant in the risk assessment process.

16 This overall approach is not time-consuming and may be applied to high throughtput 17 screening of high numbers of samples. It allows to take a first 'fingerprint' of tested 18 dietary contaminants at realistic exposure, which may be useful for further risk 19 assessment studies and for limiting in vivo testing. The proposed experimental toolbox, 20 which gathers diverse yet existing test systems, offers an additional dimension in 21 comparison with the in vitro assays taken separately. In the scope of emerging risk 22 detection, this tool is very promising due to the diversity and complementarities of 23 endpoints measured and the biological relevance of the concentrations selected for the 24 experimental studies.

\section{Acknowledgments}

27 This study was funded by the Belgian Federal Public Service of Health, Food Chain, 28 Safety and Environment (contract RT 05/07 EMRISK). 
Aarts, J. M. M. J. G., Haan, L. H. J. d., Schalk, J. A. C., Cox., M. A. and Brouwer, A. (1993). Ah receptor-mediated luciferase expression: a tool for monitoring dioxin-like toxicity. Organohalogen Compound 13: 361. Ashida, H., Nishiumi, S. and Fukuda, I. (2008). An update on the dietary ligands of the AhR. Expert Opinion on Drug Metabolism \& Toxicology 4(11): 1429-1447.

Banks, D. and Soliman, M. R. I. (1997). Protective effects of antioxidants against benomyl-induced lipid peroxidation and glutathione depletion in rats. Toxicology 116: 177-181.

Berger, V., Gabriel, A. F., Sergent, T., Trouet, A., Larondelle, Y. and Schneider, Y. J. (2003). Interaction of ochratoxin A with human intestinal Caco-2 cells: possible implication of a multidrug resistance-associated protein (MRP2). Toxicology Letters 140141: 465-476.

Bock, K. W. and Köhle, C. (2006). Ah receptor: Dioxin-mediated toxic responses as hints to deregulated physiologic functions. Biochemical Pharmacology 72(4): 393-404.

Bony, S., Carcelen, M., Olivier, L. and Devaux, A. (2006). Genotoxicity assessment of deoxynivalenol in the Caco- 2 cell line model using the Comet assay. Toxicology Letters 166(1): 67-76.

Boulenc, X., Bourrie, M., Fabre, I., Roque, C., Joyeux, H., Berger, Y. and Fabre, G. (1992). Regulation of cytochrome P4501A1 gene expression in a human intestinal cell line, Caco-2. The journal of pharmacology and experimental therapeutics 263(3): 14711478.

Braniste, V., Leveque, M., Buisson-Brenac, C., Bueno, L., Fioramonti, J. and Houdeau, E. (2009). Oestradiol decreases colonic permeability through oestrogen receptor $\beta$ mediated up-regulation of occludin and junctional adhesion molecule-A in epithelial cells. J Physiol 587(13): 3317-3328.

28 Buchthal, J., Grund, K. E., Buchmann, A., Schrenk, D., Beaune, P. and Bock, K. W. (1995). Induction of cytochrome P4501A by smoking or omeprazole in comparison with UDP-glucuronosyltransferase in biopsies of human duodenal mucosa. European Journal of Clinical Pharmacology 47(5): 431-435.

Cani, P. D. and Delzenne, N. M. (2009). Interplay between obesity and associated metabolic disorders: new insights into the gut microbiota. Current Opinion in 34 Pharmacology 9: 737-743.

35 Cetin, Y. and Bullerman, L. B. (2005). Cytotoxicity of Fusarium mycotoxins to mammalian cell cultures as determined by the MTT bioassay. Food and Chemical Toxicology 43(5): 755-764.

38 Claeys, W. L., De Voghel, S., Schmita, J.-F., Vromman, V. and Pussemier, L. (2008). vegetable consumption. Food Additives and Contaminants 25(7): 851-863.

Creppy, E. E., Chiarappa, P., Baudrimont, I., Borracci, P., Moukha, S. and Carratu, M. R. (2004). Synergistic effects of fumonisin B1 and ochratoxin A: are in vitro cytotoxicity data predictive of in vivo acute toxicity? Toxicology 201(1-3): 115-123.

Dardenne, F., Dongen, S. V., Nobels, I., Smolders, R., Coen, W. D. and Blust, R. (2008). Mode of action clustering of chemicals and environmental samples on the bases of 46 bacterial stress gene inductions. Toxicological Sciences 101(2): 206-214. 
Dardenne, F., Nobels, I., Coen, W. D. and Blust, R. (2007). Dose-response relationships and statistical performance of a battery of bacterial gene profiling assays. Environmental Biotechnology 75: 223-234. Delescluse, C., Lemaire, G., de Sousa, G. and Rahmani, R. (2000). Is CYP1A1 induction always related to AHR signaling pathway? Toxicology 153: 73-82.

Denison, M. S. and Nagy, S. R. (2003). Activation of the aryl hydrocarbon receptor by structuraly diverse exogenous and endogenous chemicals. Annual review of Pharmacology and Toxicology 43: 309-334.

Denison, M. S. and Whitlock, J. P., Jr. (1995). Xenobiotic-inducible transcription of cytochrome P450 genes. The Journal of Biological Chemistry 270(31): 18175-18178.

Dierickx, P. J. (1999). CYP1/2 activation and glutathione-dependent cytotoxicity of four pesticides in Hep G2 and Fa32 cells. Toxicology in Vitro 13(4-5): 779-783.

Dougherty, C. P., Holtz, S. H., Reinert, J. C., Panyacosit, L., Axelrad, D. A. and Woodruff, T. J. (2000). Dietary exposures to food contaminants across the United States. Environmental Research 84(2): 170-185.

Dresser, G. K., Spence, J. D. and Bailey, D. G. (2000). Pharmacokineticpharmacodynamic consequences and clinical relevance of cytochrome P450 3A4 inhibition. Clinical Pharmacokinetics 38(1): 41-57.

EC (2002). Assessment of dietary intake of Ochratoxin A by the population of EU Member states. Brussels, European Commission : Health and Consumers protection directorate-general: 1-153.

EC (2003). Collection of occurrence data of Fusarium toxins in food and assessment of dietary intake by the population of EU Member States. Brussels, European Commission : Health and Consumers protection directorate-general: 1-606.

EFSA (2004). Opinion of the scientific panel on contaminants in the food chain on a request from the commission related to ochratoxin $\mathrm{A}$ as undesirable substance in animal feed. The EFSA Journal 101: 1-36.

EFSA (2006). Opinion of the Scientific Panel on Contaminants in the Food Chain on a request from the commission related to ochratoxin A in food. The EFSA Journal 365: 156.

EFSA (2007). Opinion of the scientific panel on plant protection products and their residues on a request from the commission on the acute reference dose (ARfD) for imazalil. The EFSA Journal 460: 1-15.

Fallone, F., Villard, P.-H., Decome, L., Sérée, E., Méo, M. d., Chacon, C., Durand, A., Barra, Y. and Lacarelle, B. (2005). PPAR- $\alpha$ activation potentiates AhR-induced CYP1A1 expression. Toxicology 216(2-3): 122-128.

Fallone, F., Villard, P.-H., Sérée, E., Rimet, O., Nguyen, Q. B., Bourgarel-Rey, V., Fouchier, F., Barra, Y., Durand, A. and Lacarelle, B. (2004). Retinoids repress Ah receptor CYP1A1 induction pathway through the SMRT corepressor. Biochemical and Biophysical Research Communications 322(2): 551-556.

Fontana, R. J., Lown, K. S., Paine, M. F., Fortlage, L., Santella, R. M., Felton, J. S., Knize, M. G., Greenberg, A. and Watkins, P. B. (1999). Effects of a chargrilled meat diet on expression of CYP3A, CYP1A, and P-glycoprotein levels in healthy volunteers. Gastroenterology 117(1): 89-98.

Gallagher, E. P., Wienkers, L. C., Stapleton, P. L., Kunze, K. L. and Eaton, D. L. (1994). Role of human microsomal and human complementary DNA-expressed cytochromes 
P4501A2 and P4503A4 in the bioactivation of aflatoxin B1. Cancer Research 54(1): 101108.

3 Ghannoum, M. A. and Rice, L. B. (1999). Antifungal agents: mode of action, 4 mechanisms of resistance, and correlation of these mechanisms with bacterial resistance. 5 Clinical Microbiology Reviews 12(4): 501-517.

6 Gibbs, M. A., Baillie, M. T., Shen, D. D., Kunze, K. L. and Thummel, K. E. (2000). 7 Persistent inhibition of CYP3A4 by ketoconazole in modified Caco-2 cells. 8 Pharmaceutical Research 17(3): 299-305.

9 Giroux, V., Lemay, F., Bernatchez, G., Robitaille, Y. and Carrier, J. C. (2008). Estrogen 10 receptor $\beta$ deficiency enhances small intestinal tumorigenesis in ApcMin/+ mice. International Journal of Cancer 123(2): 303-311. transcription by the pregnane $\mathrm{X}$ receptor. Annual Review of Pharmacology and Toxicology 42: 1-23.

Grodstein, F., Newcomb, P. A. and Stampfer, M. J. (1999). Postmenopausal hormone therapy and the risk of colorectal cancer: a review and meta-analysis. The American Journal of Medicine 106(5): 574-582.

Guengerich, F. P. (1997). Role of cytochrome P450 enzymes in drug-drug interactions. Advances in Pharmacology 43: 7-35.

Guengerich, F. P. (1999). Cytochrome P-450 3A4: Regulation and Role in Drug Metabolism. Annual Review of Pharmacology and Toxicology 39: 1-17.

Guengerich, F. P. and Shimada, T. (1998). Activation of procarcinogens by human cytochrome P450 enzymes. Mutation Research 400(1-2): 201-213.

Hewitt, M. J., Mutch, P. and Pratten, M. K. (2005). Potential teratogenic effects of benomyl in rat embryos cultured in vitro. Reproductive Toxicology 20(2): 271-280.

Hou, X.-L., Takahashi, K., Kinoshita, N., Qiu, F., Tanaka, K., Komatsu, K., Takahashi, K. and Azuma, J. (2007). Possible inhibitory mechanism of Curcuma drugs on CYP3A4 in $1 \alpha, 25$ dihydroxyvitamin D3 treated Caco-2 cells. International Journal of Pharmaceutics 337(1-2): 169-177.

IARC (1993). Ochratoxin A. IARC Monographs on the Evaluation of Carcinogenic Risks to Humans 56: 489-521.

Igbedioh, S. O. and Akinyele, I. O. (1992). Effect of benomyl toxicity on some constituents of albino rats. Archives of Environmental Health 47(4): 314-317.

Kamp, H. G., Eisenbrand, G., Schlatter, J., Wurth, K. and Janzowski, C. (2005). Ochratoxin A: induction of (oxidative) DNA damage, cytotoxicity and apoptosis in mammalian cell lines and primary cells. Toxicology 206(3): 413-425.

Kawajiri, K. and Fujii-Kuriyama, Y. (2007). Cytochrome P450 gene regulation and physiological functions mediated by the aryl hydrocarbon receptor. Archives of Biochemistry and Biophysics. Highlight Issue: Enzymology of drug metabolism and toxicology 464(2): 207-212.

Kawano, N., Koji, T., Hishikawa, Y., Murase, K., Murata, I. and Kohno, S. (2004). Identification and localization of estrogen receptor $\alpha$ - and $\beta$-positive cells in adult male and female mouse intestine at various estrogen levels. Histochemistry and Cell Biology 121(5): 399-405. 
malondialdehyde levels, DNA methylation and fragmentation, and viability in Caco-2 cells. Toxicon 49(3): 306-317.

Kouadio, J. H., Mobio, T. A., Baudrimont, I., Moukha, S., Dano, S. D. and Creppy, E. E. (2005). Comparative study of cytotoxicity and oxidative stress induced by deoxynivalenol, zearalenone or fumonisin B1 in human intestinal cell line Caco-2. Toxicology 213: 56-65.

Kroes, R., Muller, D., Lambe, J., Lowik, M. R., van Klaveren, J., Kleiner, J., Massey, R., Mayer, S., Urieta, I., Verger, P. and Visconti, A. (2002). Assessment of intake from the diet. Food and Chemical Toxicology 40(2-3): 327-385.

Lampen, A., Bader, A., Bestmann, T., Winkler, M., Witte, L. and Borlak, J. T. (1998). Catalytic activities, protein- and mRNA-expression of cytochrome P450 isoenzymes in intestinal cell lines. Xenobiotica 28(5): 429-441.

Lampen, A., Meyer, S., Arnhold, T. and Nau, H. (2000). Metabolism of vitamin A and its active metabolite all-trans-retinoic acid in small intestinal enterocytes. Journal of Pharmacology and Experimental Therapeutics 295(3): 979-985.

Laparra, J. M. and Sanz, Y. (2010). Interactions of gut microbiota with functional food components and nutraceuticals. Pharmacological Research 61: 219-225.

le Maire, A., Bourguet, W. and Balaguer, P. (2010). A structural view of nuclear hormone receptor: endocrine disruptor interactions. Cellular and Molecular Life Sciences 67(8): 1219-1237.

Lee, A. J., Cai, M. X., Thomas, P. E., Conney, A. H. and Zhu, B. T. (2003). Characterization of the oxidative metabolites of $17 \beta$-estradiol and estrone formed by 15 selectively expressed human cytochrome P450 isoforms. Endocrinology 144(8): 33823398.

Lemaire, G., Mnif, W., Mauvais, P., Balaguer, P. and Rahmani, R. (2006a). Activation of $\alpha$ - and $\beta$-estrogen receptors by persistent pesticides in reporter cell lines. Life Sciences 79: 1160-1169.

Lemaire, G., Mnif, W., Pascussi, J.-M., Pillon, A., Rabenoelina, F., Fenet, H. 1. n., Gomez, E., Casellas, C., Nicolas, J.-C., Cavailles, V., Duchesne, M.-J. and Balaguer, P. (2006b). Identification of new human pregnane $\mathrm{X}$ receptor ligands among pesticides using a stable reporter cell system. Toxicological Sciences 91(2): 501-509.

Lindell, M., Karlsson, M. O., Lennernäs, H., Påhlman, L. and Lang, M. A. (2003). Variable expression of CYP and Pgp genes in the human small intestine. European Journal of Clinical Investigation 33(6): 493-499.

Looijer-van Langen, M., Hotte, N., Dieleman, L. A., Albert, E., Mulder, C. and Madsen, K. L. (2011). Estrogen receptor $\beta$ signaling modulates epithelial barrier function. American Journal of Physiology - Gastrointestinal and Liver Physiology.

Lown, K. S., Bailey, D. G., Fontana, R. J., Janardan, S. K., Adair, C. H., Fortlage, L. A., Brown, M. B., Guo, W. and Watkins, P. B. (1997). Grapefruit juice increases felodipine oral availability in humans by decreasing intestinal CYP3A protein expression. The Journal of Clinical Investigation 99(10): 2545-2553.

Ma, Q. (2001). Induction of CYP1A1. The AhR/DRE Paradigm: transcription, Receptor Regulation, and Expanding Biological Roles. Current Drug Metabolism 2: 149-164.

Maaroufi, K., Achour, A., Betbeder, A. M., Hammami, M., Ellouz, F., Creppy, E. E. and Bacha, H. (1995). Foodstuffs and human blood contamination by the mycotoxin 
1 ochratoxin A: correlation with chronic interstitial nephropathy in Tunisia. Archives of 2 toxicology 69: 552-558.

3 Maresca, M., Mahfoud, R., Garmy, N. and Fantini, J. (2002). The mycotoxin 4 deoxynivalenol affects nutrient absorption in human intestinal epithelial cells. J Nutr 5 132(9): 2723-2731.

6 Marill, J., Cresteil, T., Lanotte, M. and Chabot, G. G. (2000). Identification of human 7 cytochrome $\mathrm{P} 450 \mathrm{~s}$ involved in the formation of all-trans-retinoic acid principal 8 metabolites. Molecular Pharmacology 58(6): 1341-1348.

9 McCarroll, N., Protzel, A., Joannou, Y., Stack, H. F., Jackson, M. A., Waters, M. D. and

10 Dearfield, K. L. (2002). A survey of EPA/OPP and open literrature on selected pesticide chemicals III. Mutagenicity and carcinogenicity of benomyl and carbendazim. Mutation Research 512: 1-35.

13 McKinlay, R., Plant, J. A., Bell, J. N. B. and Voulvoulis, N. (2008). Calculating human

14 exposure to endocrine disrupting pesticides via agricultural and non-agricultural exposure routes. Science of The Total Environment 398(1-3): 1-12.

McSorley, L. C. and Daly, A. K. (2000). Identification of human cytochrome P450 isoforms that contribute to all-trans-retinoic acid 4-hydroxylation. Biochemical Pharmacology 60(4): 517-526. Wild, C. P. (2003). Development of a urinary biomarker of human exposure to deoxynivalenol. Food and Chemical Toxicology 41(2): 265-273.

Mimura, J. and Fujii-Kuriyama, Y. (2003). Functional role of AhR in the expression of toxic effects by TCDD. Biochimica et Biophysica Acta (BBA) - General Subjects 1619(3): 263-268. (2004). A benzimidazole fungicide, benomyl, and its metabolite, carbendazim, induce aromatase activity in a human ovarian granulose-like tumor cell line (KGN). Endocrinology 145(4): 1860-1869. potential roles in disease pathogenesis. Current Drug Metabolism 7(1): 67-81. of cytochrome $\mathrm{P} 450$ isoforms by imazalil, a food contaminant, in mouse small intestine and liver. Xenobiotica 27(12): 1215-1223. ortho-phenylphenol, thiabendazole and imazalil, on isolated rat hepathocytes. Life Sciences 57(15): 1433-1440.

37 Nebert, D., Dalton, T., Okey, A. and Gonzalez, F. (2004). Role of aryl hydrocarbon 38 receptor-mediated induction of the CYP1 enzymes in environmental toxicity and cancer. 
Ohtake, F., Baba, A., Fujii-Kuriyama, Y. and Kato, S. (2008). Intrinsic AhR function underlies cross-talk of dioxins with sex hormone signalings. Biochemical and Biophysical Research Communications 370: 541-546.

Ohtake, F., Fujii-Kuriyama, Y. and Kato, S. (2009). AhR acts as an E3 ubiquitin ligase to modulate steroid receptor functions. Biochemical Pharmacology 77: 474-484.

Orser, C. S., Foong, F. C. F., Capaldi, S. R., Nalezny, J., Mackay, W. and Benjamin, M. (1995). Use of prokaryotic stress promotors as indicators of the mechanisms of chemical toxicity. In vitro Toxicology 8: 71-85.

Osborne, C., Wakeling, A. and Nicholson, R. (2004). Fulvestrant: an oestrogen receptor antagonist with a novel mechanism of action. British Journal of Cancer 90: S2-S6.

Paine, M. F., Hart, H. L., Ludington, S. S., Haining, R. L., Rettie, A. E. and Zeldin, D. C. (2006). The human intestinal cytochrome P450 "pie". Drug Metabolism and Disposition 34(5): 880-886.

Paine, M. F., Khalighi, M., Fisher, J. M., Shen, D. D., Kunze, K. L., Marsh, C. L., Perkins, J. D. and Thummel, K. E. (1997). Characterization of interintestinal and intraintestinal variations in human CYP3A-dependent metabolism. Journal of Pharmacology and Experimental Therapeutics 283(3): 1552-1562.

Paine, M. F., Schmiedlin-Ren, P. and Watkins, P. B. (1999). Cytochrome P-450 1A1 expression in human small bowel: interindividual variation and inhibition by ketoconazole. Drug Metabolism and Disposition 27(3): 360-364.

Parl, F. F., Dawling, S., Roodi, N. and Crooke, P. S. (2009). Estrogen metabolism and breast cancer. Annals of the New York Academy of Sciences 1155(1): 68-75.

Pestka, J. J. and Smolinski, A. T. (2005). Deoxynivalenol: toxicology and potential effects on humans. Journal of Toxicology and Environmental Health Part B: Critical Reviews 8(1): 39-69.

Petzinger, E. and Ziegler, K. (2000). Ochratoxin A from a toxicological perspective. Journal of Veterinary Pharmacology and Therapeutics 23(2): 91-98.

Pfohl-Leszkowicz, A. and Manderville, R. A. (2007). Ochratoxin A: An overview on toxicity and carcinogenicity in animals and humans. Molecular Nutrition \& Food Research 51: 61-99.

Poulsen, M. E. and Andersen, J. H. (2003). Results from the monitoring of pesticide residues in fruit and vegetables on the Danish market, 2000-01. Food Additives and Contaminants 20(8): 742-757.

Prueksaritanont, T., Gorham, L. M., Hochman, J. H., Tran, L. O. and Vyas, K. P. (1996). Comparative studies of drug-metabolizing enzymes in dog, monkey, and human small intestines, and in Caco-2 cells. Drug Metabolism and Disposition 24(6): 634-642.

Quillardet, P. and Hofnung, M. (1985). The SOS Chromotest, a colorimetric bacterial assay for genotoxins-procedures. Mutation Research 147: 65-78.

Radic, B., Fuchs, R., Peraica, M. and Lucic, A. (1997). Ochratoxin A in human sera in the area with endemic nephropathy in Croatia. Toxicology Letters 91(2): 105-109.

Rey-Grobellet, X., Ferre, N., Eeckhoutte, C., Larrieu, G., Pineau, T. and Galtier, P. (1996). Structural requirements for the induction of cytochromes P450 by benzimidazole anthelmintic derivatives in cultured rabbit hepatocytes. Biochemical and Biophysical Research Communications 220: 789-794.

Ringot, D., Chango, A., Schneider, Y.-J. and Larondelle, Y. (2006). Toxicokinetics and toxicodynamics of ochratoxin A, un update. Chemico-Biological Interactions 159: 18-46. 
1 Rosenberg, D. W. and Leff, T. (1993). Regulation of cytochrome P450 in cultured human 2 colonic cells. Archives of Biochemistry and Biophysics 300(1): 186-192.

3 Rotter, B. A., Prelusky, D. B. and Pestka, J. J. (1996). Toxicology of deoxynivalenol 4 (vomitoxin). Journal of Toxicology and Environmental Health 48(1): 1-34.

5 SCF (1998). Opinion of the Scientific Committee on Food on Ochratoxin A. Brussels, 6 European Commission : Health and Consumers protection directorate-general: 9.

7 SCF (2002). Opinion of the Scientific Committee on Food on Fusarium toxins. Part 6 : 8 Group evaluation of T-2 toxin, HT-2 toxin, nivalenol and deoxynivalenol. Brussels, 9 European Commission : Health and Consumers protection directorate-general: 12.

10 Schmiedlin-Ren, P., Thummel, K. E., Fisher, J. M., Paine, M. F., Lown, K. S. and Watkins, P. B. (1997). Expression of enzymatically active CYP3A4 by Caco-2 cells grown on extracellular matrix-coated permeable supports in the presence of $1 \alpha, 25$ dihydroxyvitamin D3. Molecular Pharmacology 51(5): 741-754.

14 Schwarz, D., Kisselev, P., Cascorbi, I., Schunck, W. H. and Roots, I. (2001). Differential metabolism of benzo[a]pyrene and benzo[a]pyrene-7,8-dihydrodiol by human CYP1A1 variants. Carcinogenesis 22(3): 453-459.

Scippo, M.-L., Argiris, C., Weerdt, C. V. D., Muller, M., Willemsen, P., Martial, J. and Maghuin-Rogister, G. (2004). Recombinant human estrogen, androgen and progesterone receptors for detection of potential endocrine disruptors. Analytical and Bioanalytical Chemistry 378: 664-669.

Sérée, E., Villard, P. H., Pascussi, J. M., Pineau, T., Maurel, P., Nguyen, Q. B., Fallone, F., Martin, P.-M., Champion, S., Lacarelle, B., Savouret, J. F. and Barra, Y. (2004). Evidence for a new human CYP1A1 regulation pathway involving PPAR- $\alpha$ and 2 PPRE sites. Gastroenterology 127(5): 1436-1445.

Sergent, T., Dupont, I., Jassogne, C., Ribonnet, L., Heiden, E. v. d., Scippo, M.-L., Muller, M., McAlister, D., Pussemier, L., Larondelle, Y. and Schneider, Y.-J. (2009). CYP1A1 induction and CYP3A4 inhibition by the fungicide imazalil in the human intestinal Caco-2 cells-Comparison with other conazole pesticides. Toxicology Letters 184(3): 159-168.

30 Sergent, T., Parys, M., Garsou, S., Pussemier, L., Schneider, Y.-J. and Larondelle, Y. 31 (2006). Deoxynivalenol transport across human intestinal Caco-2 cells and its effects on 32 cellular metabolism at realistic intestinal concentrations. Toxicology Letters 164(2): 16733176.

34 Sergent, T., Ribonnet, L., Kolosova, A., Garsou, S., Schaut, A., De Saeger, S., Van 35 Peteghem, C., Larondelle, Y., Pussemier, L. and Schneider, Y.-J. (2008). Molecular and 36 cellular effects of food contaminants and secondary plant components and their plausible interactions at the intestinal level. Food and Chemical Toxicology 46(3): 813-841.

Shimada, T. and Guengerich, F. P. (1989). Evidence for cytochrome P-450NF, the nifedipine oxidase, being the principal enzyme involved in the bioactivation of aflatoxins in human liver. Proceedings of the National Academy of Sciences of the United States of America 86(2): 462-465.

Shimada, T., Oda, Y., Gillam, E. M., Guengerich, F. P. and Inoue, K. (2001). Metabolic activation of polycyclic aromatic hydrocarbons and other procarcinogens by cytochromes 45 Salmonella typhimurium NM2009. Drug Metabolism and Disposition 29(9): 1176-1182. 
Singh, S., Poulsom, R., Hanby, A. M., Rogers, L. A., Wright, N. A., Sheppard, M. C. and Langman, M. J. S. (1998). Expression of oestrogen receptor and oestrogen-inducible genes pS2 and ERD5 in large bowel mucosa and cancer. The Journal of Pathology 184(2): 153-160.

Sousa, T., Paterson, R., Moore, V., Carlsson, A., Abrahamsson, B. and Basit, A. W. (2008). The gastrointestinal microbiota as a site for the biotransformation of drugs. International Journal of Pharmaceutics 363: 1-25.

Stoev, S. D. (1998). The role of ochratoxin A as a possible cause of Balkan endemic nephropathy and its risk evaluation. Veterinary and human toxicology 40(6): 352-360.

Studer-Rohr, I., Schlatter, J. and Dietrich, D. R. (2000). Kinetic parameters and intraindividual fluctuations of ochratoxin A plasma levels in humans. Archives of toxicology 74(9): 499-510.

Takeuchi, S., Iida, M., Yabushita, H., Matsuda, T. and Kojima, H. (2008). In vitro screening for aryl hydrocarbon receptor agonistic activity in 200 pesticides using a highly sensitive reporter cell line, DR-EcoScreen cells, and in vivo mouse liver cytochrome P450-1A induction by propanil, diuron and linuron. Chemosphere 74: 155-165.

Takeuchi, S., Matsuda, T., Kobayashi, S., Takahashi, T. and Kojima, H. (2006). In vitro screening of 200 pesticides for agonistic activity via mouse peroxisome proliferatoractivated receptor (PPAR) $\alpha$ and PPAR $\gamma$ and quantitative analysis of in vivo induction pathway. Toxicology and Applied Pharmacology 217: 235-244.

Tsuchiya, Y., Nakajima, M. and Yokoi, T. (2005). Cytochrome P450-mediated metabolism of estrogens and its regulation in human. Cancer Letters 227(2): 115-124.

Uno, S., Dalton, T. P., Derkenne, S., Curran, C. P., Miller, M. L., Shertzer, H. G. and Nebert, D. W. (2004). Oral exposure to benzo[a]pyrene in the mouse: detoxication by inducible cytochrome P450 is more important than metabolic activation. Molecular Pharmacology 65(5): 1225-1237.

Van De Walle, J., Romier, B., Larondelle, Y. and Schneider, Y.-J. (2008). Influence of deoxynivalenol on NF- $\mathrm{kB}$ activation and IL-8 secretion in human intestinal Caco-2 cells. Toxicology Letters 177(3): 205-214.

Van der Heiden, E., Bechoux, N., Muller, M., Sergent, T., Schneider, Y.-J., Larondelle, Y., Maghuin-Rogister, G. and Scippo, M.-L. (2009). Food flavonoid aryl hydrocarbon receptor-mediated agonistic/antagonistic/synergic activities in human and rat reporter gene assays. Analytica Chimica Acta 637: 337-345.

Vanden Bossche, H., Engelen, M. and Rochette, F. (2003). Antifungal agents of use in animal health - chemical, biochemical and pharmacological aspects. Journal of Veterinary Pharmacology and Therapeutics 26: 5-29.

Verger, P. (2006). Méthodes classiques d'évaluation du risque. Analyse des risques alimentaires. E. T. DOC. Lassay-les-Châteaux, Lavoisier: 125-141.

Vinggaard, A. M., Hnida, C., Breinholt, V. and Larsen, J. C. (2000). Screening of selected pesticides for inhibition of CYP19 aromatase activity in vitro. Toxicology in Vitro 14: 227-234.

Vrabcheva, T., Usleber, E., Dietrich, R. and Martlbauer, E. (2000). Co-occurrence of ochratoxin A and citrinin in cereals from Bulgarian villages with a history of Balkan endemic nephropathy. Journal of Agricultural and Food Chemistry 48(6): 2483-2488. WHO (1997). Guidelines for predicting dietary intake of pesticide residues (revised). Geneva, World health Organization: 1-33. 
1 WHO (2001). Evaluation of certain mycotoxins in food: fifty-sixth report of the Joint 2 FAO/WHO Expert Committee on Food Additives. Geneva, World Health Organization: 3 1-62.

4 WHO (2003). GEMS/Food regional diets. Geneva, World health Organization, Food 5 Safety Department: 1-27.

6 Willemsen, P., Scippo, M.-L., Kausel, G., Figueroa, J., Maghuin-Rogister, G., Martial, J. 7 A. and Muller, M. (2004). Use of reporter cell lines for detection of endocrine-disrupter 8 activity. Analytical and Bioanalytical Chemistry 378: 655-663.

9 Zhang, Q. Y., Dunbar, D., Ostrowska, A., Zeisloft, S., Yang, J. and Kaminsky, L. S. 10 (1999). Characterization of human small intestinal cytochromes P-450. Drug Metabolism 11 and Disposition 27(7): 804-809.

12 Zhou, H. R., Lau, A. S. and Pestka, J. J. (2003). Role of double-stranded RNA-activated 13 protein kinase $\mathrm{R}$ (PKR) in deoxynivalenol-induced ribotoxic stress response. 14 Toxicological Sciences 74(2): 335-344. 
Figure 1: Chemical structure of food contaminants investigated in the present study: ochratoxin A (OTA), deoxynivalenol (DON), imazalil (IMA) and benomyl (BEN).

Figure 2: Prokaryotic gene expression profile after exposure of $E$. Coli strains to a concentration range of (A) DON $(0.031-2 \mu \mathrm{g} / \mathrm{ml})$ and (B) IMA $(0.4-13 \mu \mathrm{g} / \mathrm{ml})$. Values are means of three independent experiments performed in triplicates and are expressed as fold inductions, calculated with formulas as described in materials and methods. An arrow indicates the calculated realistic intestinal concentration. The different genes are responsive to: $k a t G$ : oxidative stress, $m i c F$ : membrane integrity and osmotic stress, osmY: osmotic stress, uspA: growth arrest, recA: SOS response, zwf: oxidative stress, $\operatorname{clpB}$ : protein perturbation, $u m u D C$ : radiation and/or chemically induced DNA damage, merR: heavy metals, ada: DNA damage (mainly methyl adducts), dinD: DNA damage, soi28: superoxide radical generating agents, $n f o$ : single- and doublestranded DNA breaks and oxidative DNA damage, SfiA: SOS response to DNA damage.

Figure 3: Modulation of CYP1A1 activity by OTA, DON, IMA and BEN in Caco-2 cells. Sixteen-day post-confluent cells seeded in 48 -well plates $\left(3.10^{4}\right.$ cells $\left./ \mathrm{cm}^{2}\right)$ were exposed to OTA (1 ng/ml), DON (250 ng/ml), IMA (2500 ng/ml) or BEN (250 ng/ml) for 6 or $24 \mathrm{~h}$. Positive controls consisted in cells treated with $\mathrm{B}[\mathrm{a}] \mathrm{P}(250 \mathrm{ng} / \mathrm{ml})$ or TCDD $(0.3 \mathrm{ng} / \mathrm{ml})$ and negative control consisted in untreated cells. CYP1A1 activity was assessed through the measurement of the fluorescence produced by the conversion of 5 $\mu \mathrm{M}$ 7-ethoxyresorufin to resorufin. Results are expressed in pmol resorufin produced $/ \mathrm{min} / \mathrm{mg}$ protein. Values are means \pm S.E.M. of three independent experiments performed in triplicates $(\mathrm{n}=9) .{ }^{* * *} P<0.005$ as compared to respective vehicle controls.

Figure 4: Modulation of CYP3A4 activity by OTA, DON, IMA and BEN in Caco-2 cells. Cells were seeded in 12-well plates $\left(4.10^{4}\right.$ cells $\left./ \mathrm{cm}^{2}\right)$ and treated during 14 days from confluence with $0.5 \mu \mathrm{M} 1,25-$ vitD $_{3}$, in order to induce CYP3A4 activity. Cells were then exposed for $3 \mathrm{~h}$ simultaneously to testosterone $(500 \mu \mathrm{M})$ and to OTA $(1 \mathrm{ng} / \mathrm{ml})$, DON (250 ng/ml), IMA (2500 ng/ml), BEN (250 ng/ml) or ketoconazole (positive control) $(26.6 \mu \mathrm{g} / \mathrm{ml})$. The CYP3A4 activity of the cells was then assessed through the 
HPLC determination of $6 \beta-(\mathrm{OH})$-testosterone in the cell medium. Non-induced cells represent the basal CYP3A4 activity without preliminary inductive treatment with 1,25vitD ${ }_{3}$. Results are expressed in pmol $6 \beta-(\mathrm{OH})$-testosterone produced/min/mg protein and illustrated in $\%$ of negative control $(5.13 \pm 0.37 \mathrm{pmol} / \mathrm{min} / \mathrm{mg}$ protein), consisting in untreated but pre-induced cells. Values are means \pm S.E.M. of three independent experiments performed in triplicates $(\mathrm{n}=9) .{ }^{*} P<0.05,{ }^{* * *} P<0.005$ as compared to respective vehicle controls.

Figure 5: Dose-response curves of E2 and BEN in MMV-Luc cells. Exposure time was $24 \mathrm{~h}$. Results are expressed as means of the relative response $(\%) \pm$ S.E.M. $(100 \%$ with highest tested concentration of E2), of two independent experiments performed in triplicates $(\mathrm{n}=6)$, in function of the ligand concentration $(\mathrm{ng} / \mathrm{ml})$. 
Table 1: Theoretical maximum daily intake (TMDI) and realistic intestinal concentration (C) of OTA and DON, estimated by a deterministic approach. European maximal legal limits (MLs) in the main consumed foodstuffs specified in the Commission Regulation (EC) $\mathrm{N}^{\circ} 1881 / 2006$ of 19 December 2006 and human European consumption data from GEMS/FOOD Regional Diets (WHO, 2003) ( $\left.\mathrm{Q}_{E i}\right)$ were used (TWI, tolerable weekly intake; TDI, tolerable daily intake; bw, body weight).

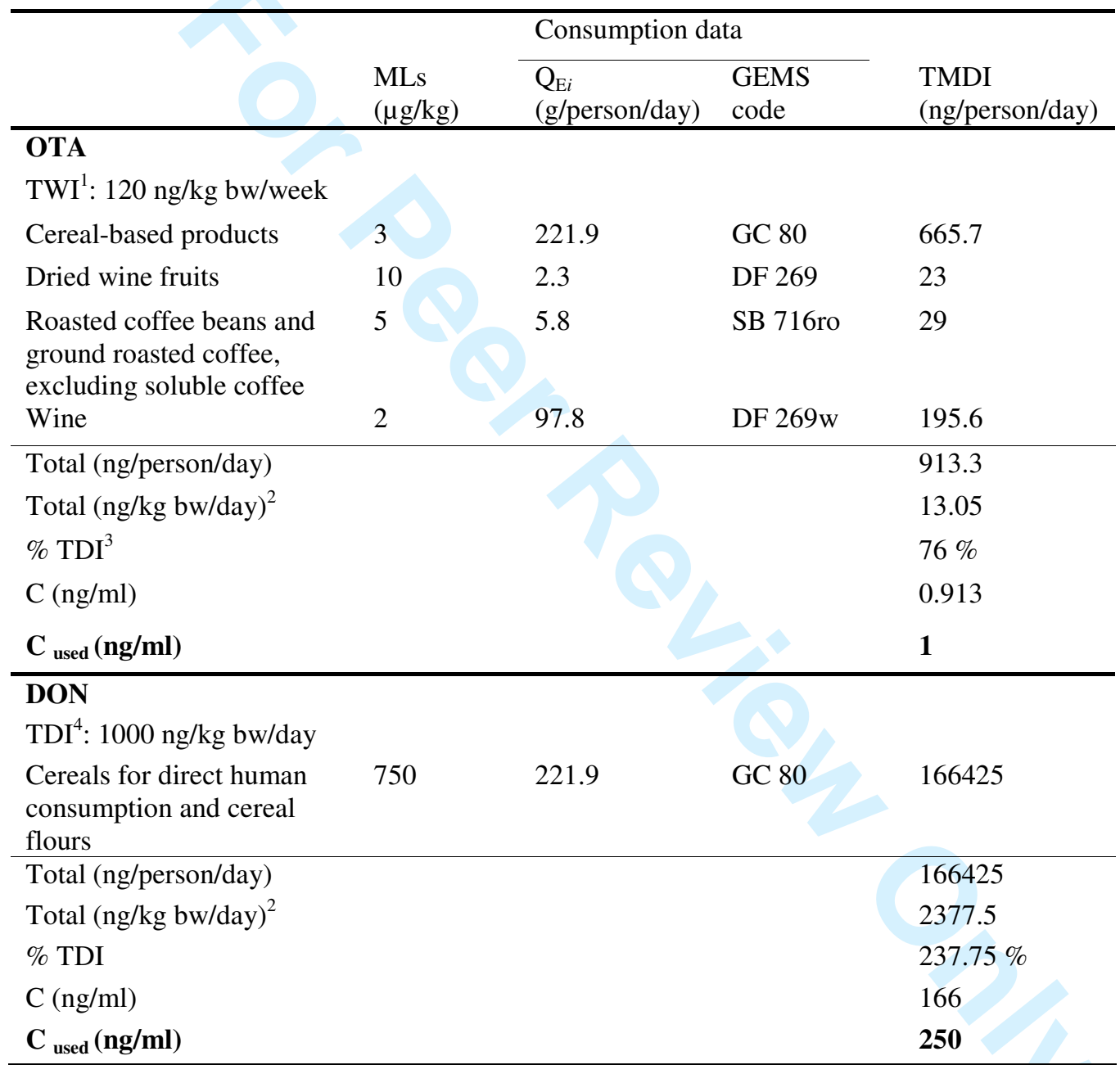

${ }^{1}$ EFSA (2006)

${ }^{2}$ Assuming a $70 \mathrm{~kg}$ body weight adult

${ }^{3}$ Assuming that the tolerable weekly intake is equally spread over the week and that TDI $=\mathrm{TWI} / 7=17.14$ $\mathrm{ng} / \mathrm{kg}$ bw/day

${ }^{4}$ SCF (2002) 
Table 2: Theoretical maximum daily intake (TMDI) and realistic intestinal concentration (C) of IMA and BEN estimated by a deterministic approach. European maximal limits of residues (MRLs) in food specified in the Commission Regulation (EC) N³96/2005 of 23 February 2005 (amended by Commission Regulation (EC) N839/2008 of 31 July 2008 for BEN and Commission Regulation (EU) $\mathrm{N}^{\mathrm{O}} 750 / 2010$ of 7 July 2010 for IMA) and human European consumption data from GEMS/FOOD Regional Diets (WHO, 2003) $\left(\mathrm{Q}_{E i}\right)$ were used (ADI, acceptable daily intake; bw, body weight).

\begin{tabular}{|c|c|c|c|c|c|c|}
\hline & \multicolumn{2}{|c|}{ Consumption data } & \multicolumn{2}{|c|}{$\begin{array}{l}\text { IMA } \\
\text { ADI }^{1}: 30 \mu \mathrm{g} / \mathrm{kg} \text { bw/day }\end{array}$} & \multicolumn{2}{|c|}{$\begin{array}{l}\text { BEN } \\
\text { ADI }^{1}: 100 \mu \mathrm{g} / \mathrm{kg} \text { bw/day }\end{array}$} \\
\hline & $\begin{array}{l}\mathrm{Q}_{\mathrm{E} i} \\
\text { (g/person/day) }\end{array}$ & $\begin{array}{l}\text { GEMS } \\
\text { code }\end{array}$ & $\begin{array}{l}\text { MRLs } \\
(\mathrm{mg} / \mathrm{kg})\end{array}$ & $\begin{array}{l}\text { TMDI } \\
(\mu \mathrm{g} / \text { person/day })\end{array}$ & $\begin{array}{l}\text { MRLs }^{2} \\
(\mathrm{mg} / \mathrm{kg})\end{array}$ & $\begin{array}{l}\text { TMDI } \\
(\mu \mathrm{g} / \text { person/day })\end{array}$ \\
\hline \multicolumn{7}{|l|}{ Cereals } \\
\hline Barley & 19.8 & GC 640 & 0.05 & 0.99 & 2 & 39.6 \\
\hline Maize & 8.8 & GC 645 & 0.05 & 0.44 & 0.01 & 0.088 \\
\hline Oats & 2 & GC 647 & 0.05 & 0.1 & 2 & 4 \\
\hline Rice & 11.8 & GC 649 & 0.05 & 0.59 & 0.01 & 0.118 \\
\hline Rye & 1.5 & GC 650 & 0.05 & 0.075 & 0.1 & 0.15 \\
\hline Wheat & 178 & GC 654 & 0.05 & 8.9 & 0.1 & 17.8 \\
\hline \multicolumn{7}{|l|}{ Fruits } \\
\hline Citrus fruits & 44.6 & $\mathrm{FC} 1$ & 5 & 223 & 0.5 & 22.3 \\
\hline Pome fruits & 51.3 & FP 9 & 2 & 102.6 & 0.2 & 10.26 \\
\hline Stone fruits & 23.3 & FS 12 & 0.05 & 1.165 & & \\
\hline Apricots & 3.5 & FS 240 & & & 0.2 & 0.7 \\
\hline Cherries & 3 & FS 13 & & & 0.5 & 1.5 \\
\hline Peaches & 12.5 & FS 247 & & & 0.2 & 2.5 \\
\hline Plums & 3.8 & FS 14 & & & 0.5 & 1.9 \\
\hline Small fruits and berries & 23.5 & FB 18 & 0.05 & 1.175 & & \\
\hline Table grapes & 13.8 & FB 269 & & & 0.3 & 4.14 \\
\hline Strawberries & 5.3 & FB 275 & & & 0.1 & 0.53 \\
\hline Blueberries & 0.5 & FB 20 & & & 0.1 & 0.05 \\
\hline Cranberries & 0.3 & FB 265 & & & 0.1 & 0.03 \\
\hline Currants & 0.3 & FB 21 & & & 0.1 & 0.03 \\
\hline Gooseberries & 0.5 & FB 268 & & & 0.1 & 0.05 \\
\hline
\end{tabular}




\begin{tabular}{|c|c|c|c|c|c|c|}
\hline Avocados & 1 & FI 326 & 0.05 & 0.05 & 0.1 & 0.1 \\
\hline Bananas & 22.8 & FI 327 & 2 & 45.6 & 0.1 & 2.28 \\
\hline Dates & 0.3 & FT 295 & 0.05 & 0.015 & 0.1 & 0.03 \\
\hline Figs & 0.5 & FT 297 & 0.05 & 0.025 & 0.1 & 0.05 \\
\hline Kiwi & 1.5 & FI 341 & 0.05 & 0.075 & 0.1 & 0.15 \\
\hline Olives & 2.8 & FT 305 & 0.05 & 0.14 & 0.1 & 0.28 \\
\hline Passion fruit & 1.5 & FI 351 & 0.05 & 0.075 & 0.1 & 0.15 \\
\hline Pineapples & 3.3 & FI 353 & 0.05 & 0.165 & 0.1 & 0.33 \\
\hline \multicolumn{7}{|l|}{ Vegetables } \\
\hline \multicolumn{7}{|l|}{ Root and tuber vegetables } \\
\hline Beetroot & 2 & VR 574 & 0.05 & 0.1 & 0.1 & 0.2 \\
\hline Carrots & 22 & VR 577 & 0.05 & 1.1 & 0.1 & 2.2 \\
\hline Parsnips & 2 & VR 588 & 0.05 & 0.1 & 0.1 & 0.2 \\
\hline Radishes & 2 & VR 494 & 0.05 & 0.1 & 0.1 & 0.2 \\
\hline Sweet potatoes & 1.3 & VR 508 & 0.05 & 0.065 & 0.1 & 0.13 \\
\hline Swedes & 2 & VR 497 & 0.05 & 0.1 & 0.1 & 0.2 \\
\hline Turnips & 2 & VR 506 & 0.05 & 0.1 & 0.1 & 0.2 \\
\hline Bulb vegetables & 32.9 & VA 35 & 0.05 & 1.645 & 0.1 & 3.29 \\
\hline \multicolumn{7}{|l|}{ Fruiting vegetables } \\
\hline Tomatoes & 66.6 & VO 448 & 0.5 & 33.3 & 0.5 & 33.3 \\
\hline Peppers & 10.4 & VO 51 & 0.05 & 0.52 & 0.1 & 1.04 \\
\hline Aubergines & 2.3 & VO 440 & 0.05 & 0.115 & 0.5 & 1.15 \\
\hline \multicolumn{7}{|l|}{ Cucurbits } \\
\hline Cucumber and gherkins & 9 & VC 424 & 0.2 & 1.8 & 0.1 & 0.9 \\
\hline Summer squash & 3.5 & VC 431 & 0.2 & 0.7 & 0.1 & 0.35 \\
\hline Melons & 18.3 & VC 46 & 2 & 36.6 & 0.1 & 1.83 \\
\hline Wintersquash & 0.5 & VC 433 & 0.05 & 0.025 & 0.1 & 0.05 \\
\hline Watermelon & 7.8 & VC 432 & 0.05 & 0.39 & 0.1 & 0.78 \\
\hline Sweetcorn & 8.3 & VO 447 & 0.05 & 0.415 & 0.1 & 0.83 \\
\hline \multicolumn{7}{|l|}{ Brassica vegetables } \\
\hline Broccoli and cauliflower & 13 & VB 404 & 0.05 & 0.65 & 0.1 & 1.3 \\
\hline Brussels sprouts & 2.7 & VB 402 & 0.05 & 0.135 & 0.5 & 1.35 \\
\hline Chinese cabbage & 0.1 & VL 466 & 0.05 & 0.005 & 0.1 & 0.01 \\
\hline Kale & 2 & VL 480 & 0.05 & 0.1 & 0.1 & 0.2 \\
\hline Kohlrabi & 0.1 & VB 405 & 0.05 & 0.005 & 0.1 & 0.01 \\
\hline Leafy vegetables & 51.7 & VL 53 & 0.05 & 2.585 & 0.1 & 5.17 \\
\hline Legume vegetables & 28.4 & VP 60 & 0.05 & 1.42 & & \\
\hline
\end{tabular}




\begin{tabular}{|c|c|c|c|c|c|c|}
\hline Beans & 12 & VP 526 & & & 0.2 & 2.4 \\
\hline Peas & 14 & VP 63 & & & 0.2 & 2.8 \\
\hline \multicolumn{7}{|l|}{ Stem vegetables } \\
\hline Asparagus & 1.5 & VS 621 & 0.05 & 0.075 & 0.1 & 0.15 \\
\hline Celery & 2 & VS 624 & 0.05 & 0.1 & 0.1 & 0.2 \\
\hline Leek & 2 & VA 384 & 0.05 & 0.1 & 0.1 & 0.2 \\
\hline Rhubarb & 2 & VS 627 & 0.05 & 0.1 & 0.1 & 0.2 \\
\hline Mushrooms & 4 & VO 450 & 0.05 & 0.2 & 1 & 4 \\
\hline Pulses & 9.4 & VD 70 & 0.05 & 0.47 & 0.1 & 0.94 \\
\hline Nuts and oilseeds & 29.9 & - & 0.05 & 1.495 & 0.1 & 2.99 \\
\hline Potatoes & 240.8 & VR 589 & 3 & 722.4 & 0.1 & 24.08 \\
\hline \multicolumn{7}{|l|}{ Stimulants } \\
\hline Tea & 2.3 & DT 171 & 0.1 & 0.23 & 0.1 & 0.23 \\
\hline Coffee beans & 7.9 & SB 716 & 0.1 & 0.79 & 0.1 & 0.79 \\
\hline Cocoa & 3.1 & SB 715 & 0.1 & 0.31 & 0.1 & 0.31 \\
\hline Chicory root & 1 & VR 469 & 0.05 & 0.05 & 0.1 & 0.1 \\
\hline Sugar beet & 2 & VR 596 & 0.05 & 0.1 & 0.1 & 0.2 \\
\hline Hops & 0.1 & DH 1100 & 0.1 & 0.01 & 0.1 & 0.01 \\
\hline \multicolumn{7}{|l|}{ Animal products } \\
\hline Meat and offal & 217.3 & - & 0.05 & 10.865 & 0.05 & 10.865 \\
\hline Eggs & 37.6 & PE 112 & 0.05 & 1.88 & 0.05 & 1.88 \\
\hline Milk & 336.1 & AO 31 & 0.05 & 16.805 & 0.05 & 16.805 \\
\hline Honey & 1.3 & - & 0.05 & 0.065 & 1 & 1.3 \\
\hline Total ( $\mu \mathrm{g} /$ person/day) & & & & 1223.3 & & 234.456 \\
\hline Total $(\mu \mathrm{g} / \mathrm{kg} \text { bw/day })^{3}$ & & & & 17.47 & & 3.34 \\
\hline$\%$ ADI & & & & $58.2 \%$ & & $3.34 \%$ \\
\hline $\mathrm{C}(\mathrm{ng} / \mathrm{ml})$ & & & & 1223 & & 234 \\
\hline $\mathrm{C}_{\text {used }}(\mathrm{ng} / \mathrm{ml})$ & & & & 2500 & & 250 \\
\hline
\end{tabular}

${ }^{1}$ Set by JMPR (http://www.inchem.org/pages/jmpr.html)

${ }^{2}$ Sum of benomyl and carbendazim, expressed as carbendazim

${ }^{3}$ Assuming a $70 \mathrm{~kg}$ body weight adult 


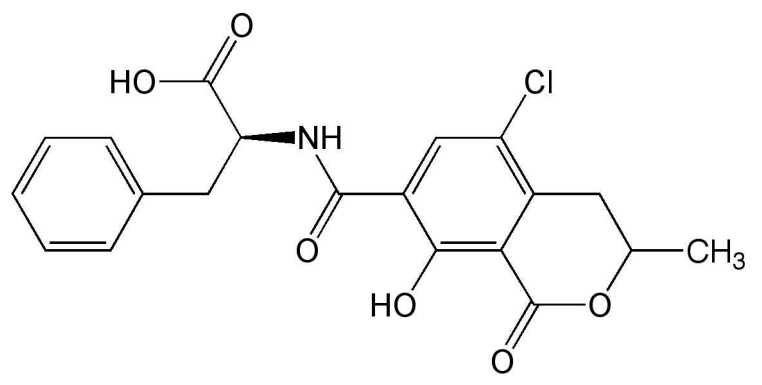

Ochratoxin A (OTA)

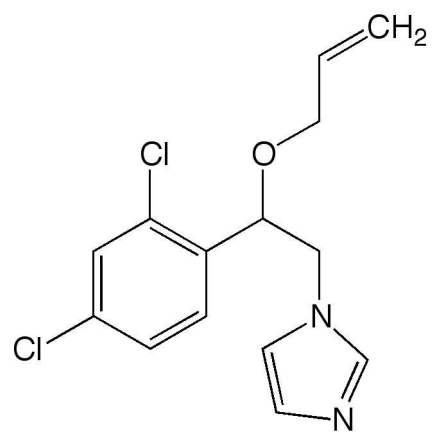

Imazalil (IMA)<smiles>CC1=CC2OC3CC(O)CC3(C(O)C1=O)C1(CO1)C2(C)CO</smiles>

Deoxynivalenol (DON)<smiles>CCCCNC(=O)n1c(NC(=O)OC)nc2ccccc21</smiles>

Benomyl (BEN)

Figure 1: Chemical structure of food contaminants investigated in the present study: ochratoxin A (OTA), deoxynivalenol (DON), imazalil (IMA) and benomyl (BEN). $171 \times 142 \mathrm{~mm}(300 \times 300 \mathrm{DPI})$ 
Figure 2: Prokaryotic gene expression profile after exposure of $\mathrm{E}$. Coli strains to a concentration range of (A) DON $(0.031-2 \mu \mathrm{g} / \mathrm{ml})$ and (B) IMA $(0.4-13 \mu \mathrm{g} / \mathrm{ml})$. Values are means of three independent experiments performed in triplicates and are expressed as fold inductions, calculated with formulas as described in materials and methods. An arrow indicates the calculated realistic intestinal concentration. The different genes are responsive to: katG: oxidative stress, micF: membrane integrity and osmotic stress, osmY: osmotic stress, uspA: growth arrest, recA: SOS response, zwf: oxidative stress, clpB: protein perturbation, umuDC: radiation and/or chemically induced DNA damage, merR: heavy metals, ada: DNA damage (mainly methyl adducts), dinD: DNA damage, soi28: superoxide radical generating agents, nfo: single- and double-stranded DNA breaks and oxidative DNA damage, SfiA: SOS response to DNA damage. $215 \times 279 \mathrm{~mm}(600 \times 600 \mathrm{DPI})$ 
Figure 2: Prokaryotic gene expression profile after exposure of $\mathrm{E}$. Coli strains to a concentration range of (A) DON $(0.031-2 \mu \mathrm{g} / \mathrm{ml})$ and $(B)$ IMA $(0.4-13 \mu \mathrm{g} / \mathrm{ml})$. Values are means of three independent experiments performed in triplicates and are expressed as fold inductions, calculated with formulas as described in materials and methods. An arrow indicates the calculated realistic intestinal concentration. The different genes are responsive to: katG: oxidative stress, micF: membrane integrity and osmotic stress, osmY: osmotic stress, uspA: growth arrest, recA: SOS response, zwf: oxidative stress, clpB: protein perturbation, umuDC: radiation and/or chemically induced DNA damage, merR: heavy metals, ada: DNA damage (mainly methyl adducts), dinD: DNA damage, soi28: superoxide radical generating agents, nfo: single- and double-stranded DNA breaks and oxidative DNA damage, SfiA: SOS response to DNA damage. $215 \times 279 \mathrm{~mm}(600 \times 600 \mathrm{DPI})$ 


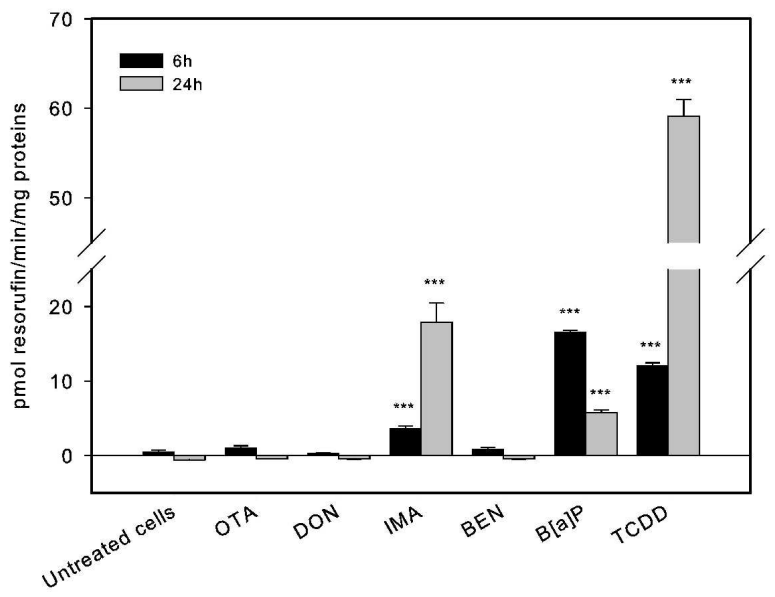

Figure 3: Modulation of CYP1A1 activity by OTA, DON, IMA and BEN in Caco-2 cells. Sixteen-day post-confluent cells seeded in 48 -well plates $(3.104$ cells/cm2) were exposed to OTA $(1 \mathrm{ng} / \mathrm{ml})$, DON $(250 \mathrm{ng} / \mathrm{ml})$, IMA $(2500 \mathrm{ng} / \mathrm{ml})$ or BEN $(250 \mathrm{ng} / \mathrm{ml})$ for 6 or $24 \mathrm{~h}$. Positive controls consisted in cells treated with $B[a] P(250 \mathrm{ng} / \mathrm{ml})$ or TCDD $(0.3 \mathrm{ng} / \mathrm{ml})$ and negative control consisted in untreated cells. CYP1A1 activity was assessed through the measurement of the fluorescence produced by the conversion of $5 \mu \mathrm{M}$ 7-ethoxyresorufin to resorufin. Results are expressed in pmol resorufin produced $/ \mathrm{min} / \mathrm{mg}$ protein. Values are means \pm S.E.M. of three independent experiments performed in triplicates $(n=9) . * * * P<0.005$ as compared to respective vehicle controls. $209 \times 296 \mathrm{~mm}(600 \times 600 \mathrm{DPI})$ 
Figure 4: Modulation of CYP3A4 activity by OTA, DON, IMA and BEN in Caco-2 cells. Cells were seeded in 12-well plates (4.104 cells/cm2) and treated during 14 days from confluence with $0.5 \mu \mathrm{M}$ 1,25-vitD3, in order to induce CYP3A4 activity. Cells were then exposed for $3 \mathrm{~h}$ simultaneously to testosterone $(500 \mu \mathrm{M})$ and to OTA $(1 \mathrm{ng} / \mathrm{ml})$, DON $(250 \mathrm{ng} / \mathrm{ml})$, IMA $(2500 \mathrm{ng} / \mathrm{ml})$, BEN $(250$ $\mathrm{ng} / \mathrm{ml}$ ) or ketoconazole (positive control) $(26.6 \mu \mathrm{g} / \mathrm{ml})$. The CYP3A4 activity of the cells was then assessed through the HPLC determination of $6 \beta-(\mathrm{OH})$-testosterone in the cell medium. Non-induced cells represent the basal CYP3A4 activity without preliminary inductive treatment with 1,25-vitD3. Results are expressed in pmol $6 \beta-(\mathrm{OH})$-testosterone produced/min/mg protein and illustrated in $\%$ of negative control $(5.13 \pm 0.37 \mathrm{pmol} / \mathrm{min} / \mathrm{mg}$ protein), consisting in untreated but pre-induced cells. Values are means \pm S.E.M. of three independent experiments performed in triplicates $(n=9)$. $* P<$ $0.05, * * * \mathrm{P}<0.005$ as compared to respective vehicle controls. $209 \times 296 \mathrm{~mm}(600 \times 600 \mathrm{DPI})$ 


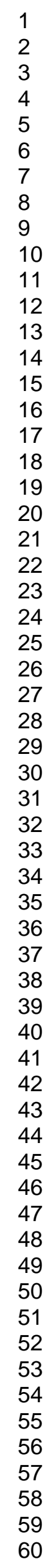


Figure 5: Dose-response curves of E2 and BEN in MMV-Luc cells. Exposure time was 24h. Results are expressed as means of the relative response (\%) \pm S.E.M. (100\% with highest tested concentration of E2), of two independent experiments performed in triplicates $(n=6)$, in function of the ligand concentration $(\mathrm{ng} / \mathrm{ml})$. $390 \times 262 \mathrm{~mm}(150 \times 150 \mathrm{DPI})$ 